\title{
Особливості забезпечення аеродинамічних характеристик регіонального пасажирського літака
}

\author{
Державне підприємство «АНТОНОВ»
}

\begin{abstract}
Наведено основні результати розрахунково-дослідних робіт, проведених при створенні регіонального пасажирського літака і виконаних для забезпечення його аеродинамічних характеристик. При створенні сімейства літаків Ан-148-100/Ан-158 досягнуто такий рівень аеродинамічної досконалості літаків, котрий забезпечив виконання заданих вимог до їх льотно-технічних характеристик, - максимальної швидкості, висоти крейсерського польоту та дальності польоту з різним комерційним навантаженням. Розроблено аеродинамічне компонування, яке дозволила створити сімейство регіональних пасажирських літаків-високопланів зі швидкістю польоту до 870 км/год ІШ (істинна швидкість) ( $\mathrm{M}=0,8)$, що не має аналогів у світовій практиці авіабудування. Розроблені для літаків Ан-148-100/Ан-158 надкритичні профрілі нового покоління з великою максимальною відносною товщиною склали основу аеродинамічного компонування швидкісного крила з помірною стрілоподібністю. Значення аеродинамічної якості літака на крейсерському режимі польоту становить $K_{\text {крейс }}=15,8$, що відповідає світовому рівню. Розроблено аеродинамічне компонування механізації крила, яке забезпечило високі несучі властивості крила на етапах зльоту та посадки, що дозволило повністю виконати вимоги до необхідних довжин злітно-посадкових смуг аеродромів базування $L_{\text {зпс }}=1485 \ldots 1950$ м. Розроблені алгоритми, котрі реалізуються в електродистанційній системі керування, забезпечили необхідні за нормами характеристики стійкості, керованості та динаміки польоту в основному режимі керування. Вибрані запаси власної статичної стійкості літака, ефективність його органів керування забезпечують безпечне завершення польоту в резервному режимі керування.

Сертифікаційні льотні випробування літаків Ан-148-100/Ан-158 підтвердили повну відповідність їх злітно-посадкових і льотно-технічних характеристик, а також характеристик стійкості, керованості та динаміки польоту вимогам Сертифрікаційного базису як в штатних, так і у відмовних ситуаціях, що виносилися на льотні випробування. Були проведені в необхідному та достатньому обсязі експериментальні роботи у низькошвидкісних і високошвидкісних аеродинамічних трубах ДП «АНТОНОВ» і ЦАГІ щодо дослідження аеродинамічних і штопорних характеристик моделей літаків Ан-148-100/Ан-158, які дозволили покращити аеродинамічне компонування літаків у цілому та окремих їх агрегатів та застосовувати результати робіт при розрахунку літаків на міцність, а також для проектування їх систем.
\end{abstract}

Ключові слова: регіональний пасажирський літак, аеродинамічні характеристики, аеродинамічне компонування, льотно-технічні характеристики, надкритичний профіль, динаміка польоту, експериментальні аеродинамічні дослідження.

Створення реактивного регіонального літака нового покоління на 75 - 85 пасажирів було обумовлено потребою ринку пасажирських авіаперевезень, насамперед у країнах СНД, викликаною припиненням польотів парку морально й фізично застарілих літаків Ту-134 внаслідок нерентабельності їхньої експлуатації, а також невідповідністю їхніх характеристик все жорсткішим вимогам Авіаційних правил з шуму та емісії.

Актуальність робіт зі створення нового реактивного регіонального літака для нашої держави підтверджується тим, що така тема була внесена до заходів «Державної комплексної програми розвитку авіаційної промисловості України на період до 2010 року», затвердженої постановою КМУ від 12.12.2001 року 
№ 1665-25, і частково фрінансувалася у частині розроблення Ан-148-100, а також капітальних витрат для організації виробництва літака.

При створенні сучасного регіонального реактивного пасажирського літака забезпечення його аеродинамічних характеристик $є$ важливим завданням.

У даній статті наведені основні результати розрахункових і експериментальних досліджень із забезпечення аеродинамічних характеристик регіонального пасажирського літака, котрі були проведені на Державному підприємстві «АНТОНОВ» при створенні сімейства літаків Ан-148-100/Ан-158.

\section{Розрахунково-дослідні роботи за вибором аеродинамічного компонування літака}

Головні вимоги до характеристик польоту за маршрутом і до базування сімейства регіональних літаків Ан-148-100/Ан-158 (рисунок 1) (Ан-148-100A, Ан-148-100B, Ан-148-100E та Ан-158) первісно визначалися затвердженим Генеральним конструктором технічним завданням, в якому були задані контрольні значення таких параметрів, як крейсерські висота та швидкість польоту, практичні дальності польоту з різним комерційним навантаженням, максимальна експлуатаційна швидкість $V_{M O}$, а також умови базування необхідні довжини злітно-посадкової смуги для зльоту та посадки.

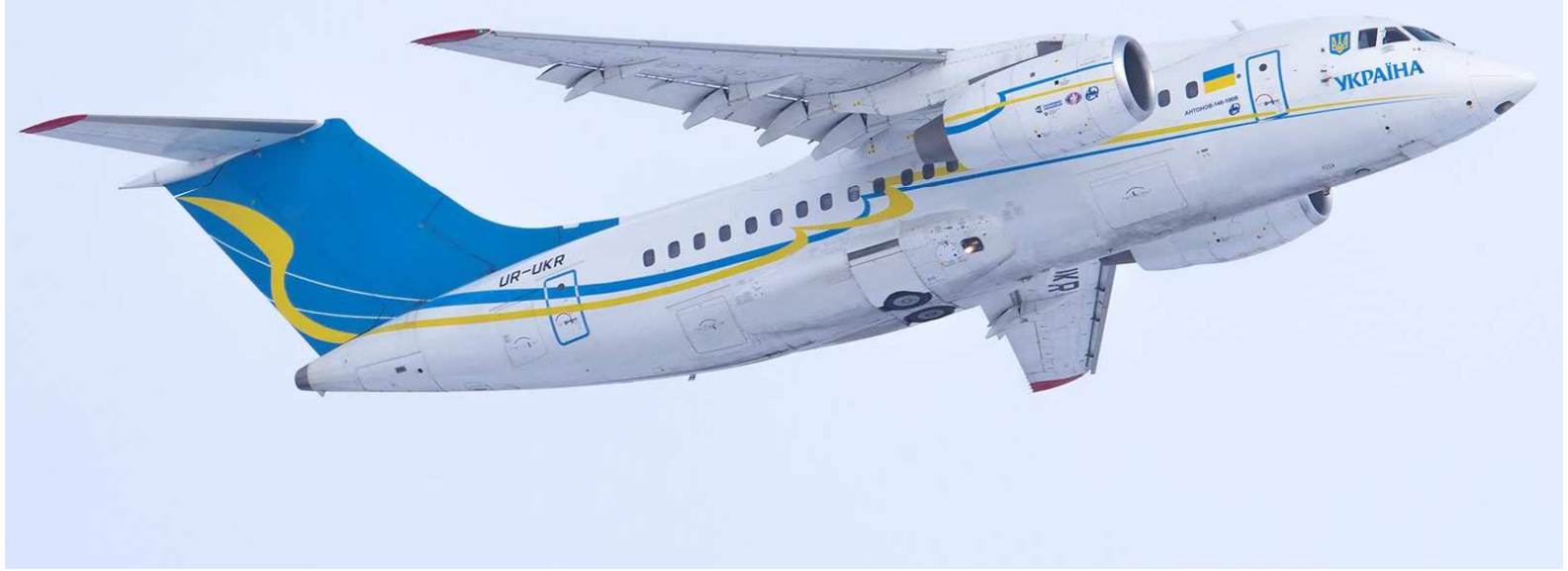

Рисунок 1 - Сучасний регіональний пасажирський літак Ан-148-100B

Безпечні умови експлуатації літака мали забезпечуватися виконанням вимог Сертифікаційного базису СБ-148, який містить вимоги Авіаційних правил СНД (Союз Незалежних Держав) АП-25 та Європи CS-25.

Досягнення необхідних льотно-технічних характеристик, стійкості та керованості забезпечувалися, перш за все, надійно розробленим аеродинамічним компонуванням літака та його головного агрегату - крила.

Розроблення аеродинамічного компонування крила. Літаки сімейства Ан-148-100/Ан-158 виконані за схемою високоплан з Т-подібним хвостовим оперенням і з двома турбореактивними двоконтурними двигунами Д-436-148, встановленими на пілонах під крилом. 
Внаслідок комплексного аналізу аеродинамічних, конструктивних, технологічних та інших вимог були вибрані такі (компромісні) геометричні характеристики крила:

- площа крила $S=87 \mathrm{~m}^{2}$;

- трапецієподібна фрорма в плані крила без передніх та задніх напливів;

- подовження $\lambda=9,58$;

- звуження $\eta=4,05$;

- стрілоподібність по лінії $1 / 4$ хорд $\chi_{1 / 4}=25^{\circ}$.

Розрахункові дослідження виконувалися за допомогою сучасних тривимірних чисельних методів CFD (комплекс програм ЦАГІ) проектування крила, які дозволили істотно зменшити обсяг трубних випробувань. Під час розрахункових досліджень оптимізувалася кількість базових аеродинамічних профрілів, самі профрілі, кути геометричної крутки, закони формування зовнішньої поверхні, параметри взаємного розташування крила та фрюзеляжу та інші характеристики.

Наприкінці розрахункових досліджень було вибрано чотири варіанти крила в польотній конфігурації: К19А, К21А, К23А та К20А для проведення порівняльних експериментальних досліджень в аеродинамічній трубі (АДТ) Т-106М ЦАГІ, в широкому діапазоні чисел Маха й Рейнольдса.

В 2000 - 2001 рр. в АДТ Т-106М ЦАГІ була випробувана модель літака Ан-148 з чотирма варіантами крила - К19А, К20А, К21А і К23А. Максимальне досягнуте критичне число Маха (коли $\left.d C_{x_{x в}} / d M=0,1\right) M_{\kappa р u m ~}=0.785$ при $C_{y}=0,45$ забезпечувалося крилом К19А. При крейсерському числі Маха $\mathrm{M}=0,78$ найбільші значення максимального коефіцієнта піднімальної сили

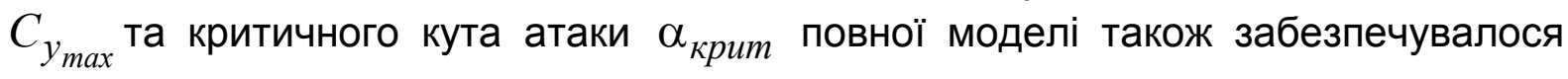
крилом К19А.

Основу аеродинамічного компонування крила К19А склали розроблені на ДП «АНТОНОВ» надкритичні профрілі П-68а.

Теоретичні контури верхньої та нижньої поверхонь крила К19А сформовані по семи базових профрілях за сплайновими залежностями вздовж розмаху крила.

Максимальна відносна товщина профрілів крила плавно зменшується від значення $\bar{c}_{\text {max }}=15,5 \%$ у бортовому перерізі до $\bar{c}_{\max }=11 \%$ у кінцевому перерізі. Застосування таких «товстих» надкритичних профрілів при достатньо високому значенні подовження крила $\lambda=9,58$ забезпечило високий рівень аеродинамічних характеристик літака на всіх етапах польоту. При значній відносній товщині профілів кесонної частини крила забезпечується збільшення місткості розташованих у кесоні крила паливних баків, що забезпечує досягнення заданої дальності польоту.

Слід зауважити, що максимальна відносна товщина профрілів крила К19А сімейства літаків Ан-148-100/Ан-158 є більшою за відносну товщину крил літаків Airbus A320 та Ан-124 (рисунок 2).

Уточнення в процесі конструктивного пророблення кута встановлення крила від 2,2 до $3^{\circ}$ та зміна положення осі геометричного кручення крила на $15 \%$ у площині хорд привело до модифікації крила, яке отримало позначення К19-4А (встановлений кут крила $\varphi_{\text {всm }}=3^{\circ}$ мінімізує аеродинамічний опір літака 
та забезпечує необхідне положення фрюзеляжу в польоті $\alpha_{\phi}=1 \ldots 2^{\circ}$ ).
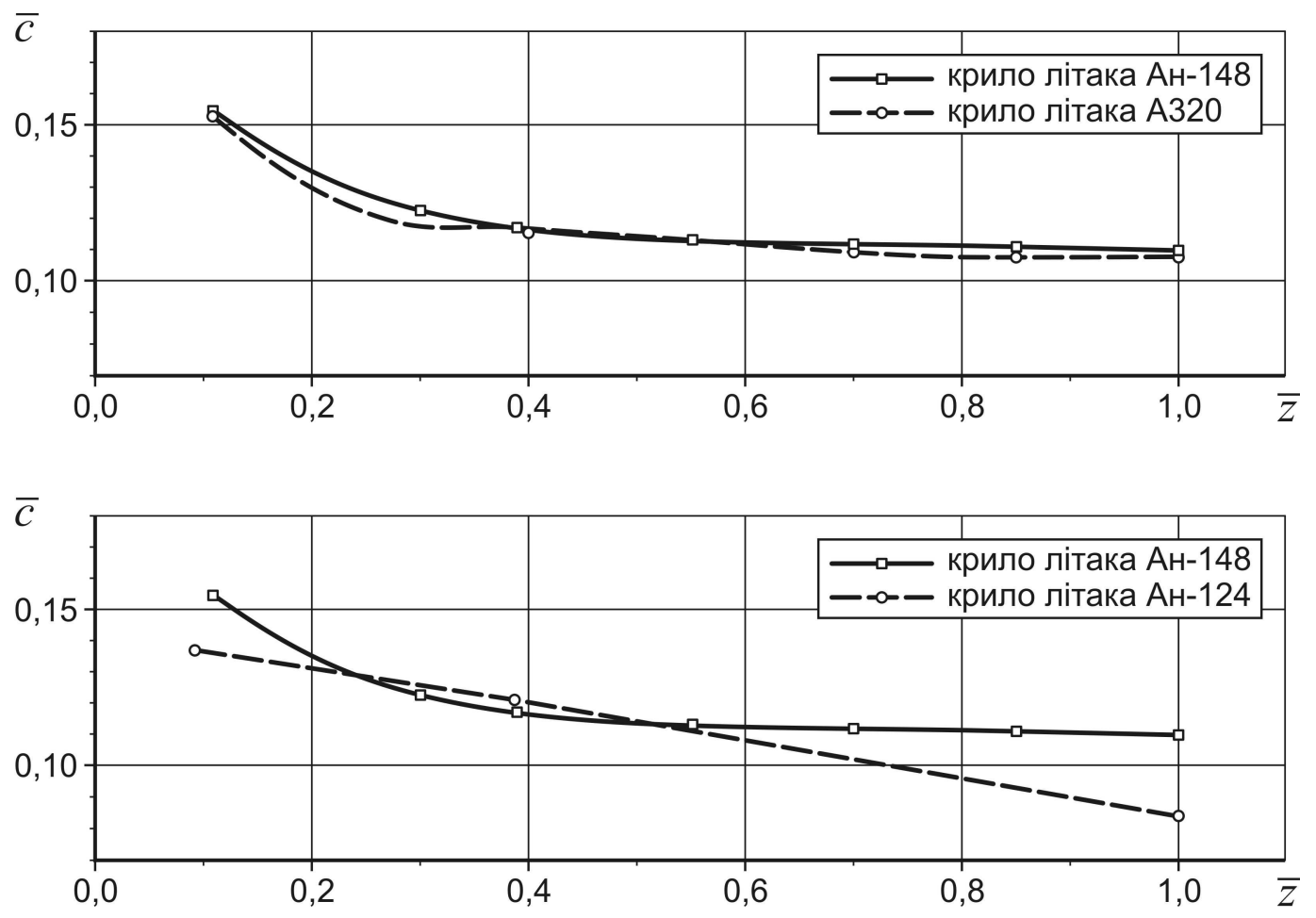

Рисунок 2 - Літак Ан-148. Залежність товщини профрілю від відносного розмаху крила

Проведене порівняння результатів досліджень профільного відсіку крила літака Ан-148 в аеродинамічній трубі АДТ-106М ЦАГІ 3 прототипами (профрілями, розробленими в ЦАГІ) показало істотну перевагу профрілю крила П-68а4 ( $\left.\bar{c}_{\max }=11,3 \%\right)$ за всіма характеристиками, що оцінювалися:

- значенням критичного числа Маха;

- несучими характеристиками $C_{y_{\max }}, C_{y_{\partial о д}}$;

- значенням ефрективної вгнутості $\left(\Delta \alpha_{0}=0,6^{\circ}\right)$;

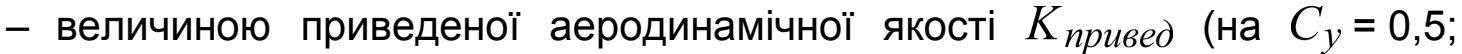
$M=0,78)$.

На основі комплексного порівняльного аналізу отриманих результатів продувок для подальшого проектування літака вибрано крило К19А.

Для забезпечення необхідної висоти пасажирського салону центроплан крила на літаках сімейства Ан-148-100/Ан-158 не «втоплений» у фюзеляж, а розташований зверху фююзеляжу.

Виконані розрахункові та експериментальні дослідження показали, що при типовому виконанні зализу крила з фюзеляжем Z1 для такого високого розташування крила відносно фюзеляжу, на крейсерських режимах польоту, в районі центроплана зароджується система прямих стрибків, які розповсюджуються за розмахом крила зі збільшенням числа М. Тому були розроблені нові варіанти зализів для збільшення критичного значення числа М та зменшення хвильового опору - зализи Z2, Z3, Z4, Z7 і Z8. Отже, за результатами комплексного аеродинамічного та вагового аналізу було 
розроблено аеродинамічне компонування зализу Z4M, яке забезпечило необхідне значення критичного числа М.

Після затвердження Генеральним конструктором аеродинамічного компонування літака в крейсерській (польотній) конфігурації була спроектована та виготовлена виконавча модель літака для проведення випробувань у високошвидкісній аеродинамічній трубі Т-106М ЦАГІ.

За результатами цих випробувань були розраховані вихідні аеродинамічні характеристики літака для визначення льотно-технічних характеристик, а також характеристик стійкості, керованості та динаміки польоту літака в польотній конфігурації.

Отримана за результатами виконавчої моделі в АДТ Т-106М-ЦАГІ та підтверджена льотними випробуваннями дослідних літаків крейсерська аеродинамічна якість літака Ан-148 $\left(M=0,75 ; C_{y}=0,5\right)$ становить $K=15,8$. Досягнутий рівень аеродинамічної досконалості літака забезпечив виконання заданих вимог до максимальної швидкості та висоти крейсерського польоту, а також до дальності польоту з різним комерційним навантаженням.

За рівнем аеродинамічної досконалості сімейство літаків Ан-148-100/ Ан-158 не поступається зарубіжним аналогам (рисунок 3).

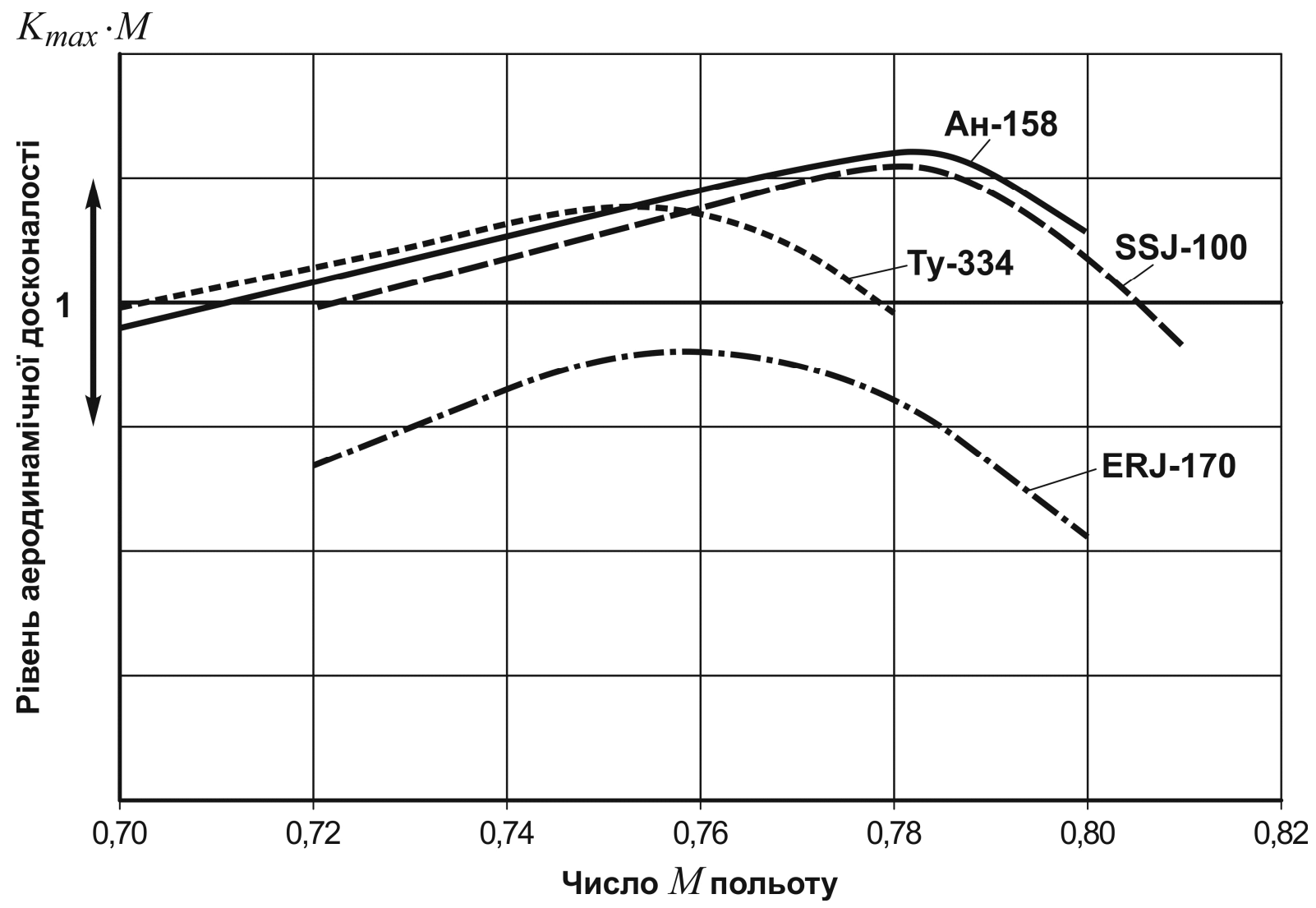

Рисунок 3 - Порівняння рівня аеродинамічної досконалості регіональних літаків

Аеродинамічне компонування літака Ан-158 відрізняється від такого компонування базового літака Ан-148 деякими особливостями - подовженим фюзеляжем, що забезпечує збільшену до 99 пасажирів місткість салону, та встановленими на крилі кінцевими аеродинамічними поверхнями. 
Аеродинамічне проектування механізації крила. Високі несучі властивості крила літака на злітно-посадкових режимах забезпечуються застосуванням ефрективної механізації задньої кромки крила у вигляді щілинних закрилків і механізації передньої кромки крила у вигляді передкрилків і відхилюваних носків.

На етапі попереднього проектування літака Ан-148-100 виходячи 3 головних вимог до базування літака були виконані у великому обсязі параметричні розрахункові дослідження щодо вибору типу механізації крила та її параметрів (відносний розмах, відносна хорда, відносні висування та кути відхилення на злітно-посадкових режимах), у тому числі з урахуванням в'язкості та відривних течій.

Для проведення експериментальних параметричних досліджень в АДТ АТ-1 ДП «АНТОНОВ» для подальшої оптимізації параметрів механізації крила був виготовлений прямокутний механізований відсік крила на характерному перерізі крила відносного розмаху $Z=0,55$.

За результатами аналітичних та експериментальних досліджень було розроблено аеродинамічне компонування механізації крила літака, яке лягло в основу підготовки математичної моделі та випуску теоретичних креслень механізації передньої та задньої кромок крила.

Прийнята та встановлена на літаку механізація крила виконана у вигляді двощілинних закрилків із фріксованим дефлектором, щілинних передкрилків на консольній частині крила та нещілинних поворотних (відхилюваних) носків на центропланній частині крила.

У результаті проведених досліджень механізації передньої кромки крила максимальний кут відхилення носка прийнятий таким: $\delta_{H K}=22^{\circ}$ (по польоту), а його відносна хорда $\bar{b}_{H \kappa}=0,096 \ldots 0,108$. Максимальний кут відхилення передкрилків $\delta_{\Pi P}=19^{\circ}$, а відносна хорда передкрилка $\bar{b}_{\Pi P}=0,133 \ldots 0,1674$. Для підвищення ефективності передкрилків управління та навіска передкрилків виконані сумісними.

Закрилки з відносною хордою $\bar{b}_{\text {закр }}=0,28 \ldots 0,30$ та відносним розмахом $\bar{l}_{\text {закр }}=0,6415$ випускаються за конічним законом. Для зльоту прийняті кути відхилення закрилків $\delta_{\text {закр }}=10$ або $20^{\circ}$, для посадки кути відхилення закрилків становлять $\delta_{\text {закр }}=20$ або $=40^{\circ}$.

На обох консолях крила розташовані по п'ять секцій інтерцепторів. Відносна хорда інтерцепторів $\bar{b}_{I H}=0,148$. Дві внутрішні секції інтерцепторів (на кожній $з$ консолей) 3 максимальним кутом відхилення $\delta_{I H}=50^{\circ}$ виконують гальмівну функцію. Три зовнішніх секції інтерцепторів (на кожній консолі) 3 максимальним кутом відхилення $\delta_{I H}=40^{\circ}$ виконують функцію елеронних, глісадних і гальмівних інтерцепторів.

Була спроектована та виготовлена механізована модель літака для випробувань в АДТ АТ-1 ДП «АНТОНОВ». Досягнуті в цих випробуваннях максимальні значення коефіцієнтів піднімальної сили $C_{y_{\max }}$ для злітнопосадкового положення механізації крила при перерахунку на натурні числа Рейнольдса забезпечили такі значення характеристик швидкостей зльоту та посадки літака, за якими вимоги до базування були повністю виконані. За результатами цих випробувань були розраховані вихідні аеродинамічні характеристики для визначення злітно-посадкових характеристик, а також характеристик стійкості, керованості та динаміки польоту. 


\section{Розрахунково-дослідні роботи для забезпечення необхідних характеристик стійкості, керованості та динаміки польоту літака}

Необхідні характеристики стійкості, керованості та динаміки польоту сімейства літаків Ан-148-100/Ан-158 (Ан-148-100A, Ан-148-100B, Ан-148-100Е, Ан-158) забезпечені засобами аеродинамічного компонування літака та засобами автоматики системи штурвального керування.

Для сімейства літаків Ан-148-100/Ан-158 вибрана схема хвостового оперення з розташуванням горизонтального оперення на вершині кіля. Така схема дозволяє зменшити розміри хвостового оперення, зменшити його опір та покращити аеродинамічну якість літака. Для спрощення конструкції стабілізатор літака виконаний нерухомим, питання повздовжнього балансування та керування вирішені застосуванням руля висоти з великою відносною хордою. Раціональність такого варіанта рішення підтверджена багатолітнім досвідом експлуатації літаків Ан (Ан-74, Ан-124 та ін.). Для вирішення питань шляхового балансування літака в польоті 3 несиметричною тягою використано руль напрямку великої відносної хорди. Органи поперечного керування складаються зі звичайних елеронів та інтерцепторів-елеронів, що являють собою поверхні крила, які відхиляються, і $€$ розташованими над носком висувних щілинних закрилків. Такі інтерцептори-елерони, ефективність яких зростає зі збільшенням кута відхилення закрилків, забезпечують отримання необхідної кутової швидкості крену на всіх режимах польоту, включаючи режим посадки літака.

Для отримання достовірних аеродинамічних характеристик літака, які впливають на його стійкість та керованість, був виконаний великий обсяг вагових випробувань моделі літака у швидкісній аеродинамічній трубі Т-106М ЦАГІ та механізованої моделі в аеродинамічній трубі АТ-1 ДП «АНТОНОВ». Вплив льодоутворення на аеродинамічні характеристики літака досліджувався на моделі ізольованого хвостового оперення літака, моделі півкрила з елероном та моделі відсіку крила із закрилком. На цих же моделях були дослідженні характеристики шарнірних моментів органів керування літака.

3 метою зменшення розмірів і ваги хвостового оперення сімейства літаків Ан-148-100/Ан-158 реалізована концепція, згідно з якою літак спроектований з пониженими запасами власної поздовжньої та шляхової статичної стійкості.

Відповідність характеристик стійкості, керованості та динаміки польоту вимогам норм льотної придатності забезпечується автоматичними системами покращення стійкості та керованості літака. Для вирішення цієї задачі на літаках Ан-148-100/Ан-158 застосована цифрова електродистанційна система керування (ЕДСК).

Допускається повна відмова ЕДСК у поздовжньому та шляховому каналах керування або всіх гідравлічних систем літака. У цих випадках система керування переходить від основного в резервний режим керування. Керування літаком за тангажем і рисканням здійснюється через механічну проводку та автономні рульові приводи (АРП). Управління за креном здійснюється за допомогою інтерцепторів-елеронів, які відхиляються автономними рульовими машинами (APM) за сигналами через електричну проводку.

Вибрані запаси власної статичної стійкості літака, ефективність його органів керування та кінематика системи керування забезпечують безпечне завершення польоту в резервному режимі керування. 
У поздовжньому та шляховому каналах резервної механічної системи керування використовують штурвальні колонки та педалі, які зв'язують важелі керування з автономними рульовими приводами. Для спрощення конструкції завантажувачі важелів керування виконані у вигляді простих («пасивних») пружин. У зв'язку з цим тримерування зусиль на важелях керування у всіх каналах здійснюється шляхом заміни сигналу переміщення важеля керування сигналом на відхилення органу керування від кнопки тримерування. Всі алгоритми роботи ЕДСК також здійснюються через відхилення відповідного органу керування. Аналогічний принцип фрормування алгоритмів ЕДСК відпрацьований на транспортному літаку Ан-70.

Алгоритм роботи системи штурвального керування літака в головному та резервному режимах керування ссрормований в результаті численних розрахунків, моделювання та досліджень на дослідно-пілотажному стенді (ДПС) з участю пілотів. Результати цієї роботи викладені у вимогах відділення аеродинаміки та динаміки польоту до системи штурвального керування сімейства літаків Ан-148-100/Ан-158.

Система керування рулем висоти в основному режимі керування забезпечує:

- зміну передаточних чисел в алгоритмах керування відповідно до положення закрилків і швидкості польоту;

- збільшення поздовжньої статичної стійкості відповідно до значень швидкості польоту та числа М;

- покращення характеристик статичної керованості відповідно до значень перевантаження та динамічної стійкості залежноі від сигналу кутової швидкості тангажа;

- обмеження кута атаки системою обмеження граничного режиму ОГР- $\alpha$;

- тактильну сигналізацію (тряска штурвалу) при наближенні до режиму звалювання.

Система керування рулем напрямку в основному режимі керування забезпечує:

- зміну передаточних чисел в алгоритмах керування відповідно до положення закрилків і швидкості польоту;

- обмеження кута ковзання системою ОГР-n

- демпфірування коливань у каналі рискання, у тому числі і взаємозв'язаних бокових коливань (типу «голландський крок»);

- координований рух при керуванні елеронами та рулем напрямку.

Система поперечного керування в основному режимі забезпечує:

- зміну нелінійних кінематичних залежностей відповідно до положення закрилків і швидкості польоту;

- демпфірування коливань у каналі крену.

Характеристики стійкості, керованості та динаміки польоту літака Ан-158 за результатами розрахункових та експериментальних досліджень, а також льотних випробувань практично не відрізняються від характеристик літака Ан-148-100.

\section{Математичне моделювання льотних характеристик і характеристик стійкості та керованості}

На етапах аеродинамічного проектування літака, його льотних випробувань і підготовки доказової документації для сертифікації застосовувалися 
математичні моделі руху літака, що основані на такому:

- аеродинамічних характеристиках літака, отриманих шляхом перерахування характеристик літаків-аналогів, і за результатами випробувань аеродинамічних моделей літака в АДТ АТ-1 ДП «АНТОНОВ» і Т-106М ЦАГІ;

- геометричних і масово-інерційних характеристиках;

- висотно-швидкісних тяго-витратних характеристиках силової установки;

- відомих рівняннях переміщення літака як матеріальної точки і як тіла 3 шістьма ступенями свободи.

За допомогою цих математичних моделей, реалізованих у вигляді комплексу програм, виконувалися розрахунки:

- злітних і посадкових характеристик із різними положеннями механізації крила в очікуваних умовах експлуатації при різних станах поверхні злітно-посадкових смуг (ЗПС);

- характеристик польоту за маршрутом, як у «сухому» повітрі, так і в умовах обледеніння;

- характеристик стійкості, керованості та динаміки польоту.

Всі розрахунки були виконані як за умови нормального функціонування двигунів і систем літака, так і при різних функціональних відмовах.

Математичні моделі льотних характеристик, отримані на підставі результатів випробувань моделей в аеродинамічних трубах, були протестовані та уточнені в процесі сертифікаційних льотних випробувань.

Створення математичних моделей льотних характеристик літака, які відповідають його фактичним характеристикам, дозволило суттєво скоротити об'єм і тривалість проведення льотних випробувань, визначити льотні характеристики літака для очікуваних умов експлуатації.

Серед основних льотних характеристик сімейства літаків Ан-148-100/ Ан-158 слід відмітити такі:

- експлуатацію на аеродромах із різним станом покриття, у т.ч. на слабо підготовлених ґрунтових і засніжених аеродромах;

- забезпечення зльоту/посадки на високогірних аеродромах (до висоти 4100 м), а також при високих температурах зовнішнього повітря;

- виконання зльоту на знижених режимах роботи двигуна (з метою підвищення ресурсних характеристик);

- виконання крейсерського польоту на висотах до 12200 м;

- забезпечення висот польоту з одним працюючим двигуном до $4000 \ldots 6000$ м, що забезпечує безпечну експлуатацію в умовах високогір'я та за високих температур зовнішнього повітря;

- виконання крейсерського польоту на швидкостях $800 \ldots 850$ км/год ІШ (істинна швидкість), що скорочує час рейсу та збільшує обіг повітряного судна.

Максимальна швидкість крейсерського польоту становить 870 км/год ІШ;

- низькі годинні витрати пального при польоті на ешелоні $1510 \ldots 1840$ кг/год;

- можливість виконання посадки за категорією IIIA ICAO.

Льотні характеристики, визначені за допомогою математичних моделей, були використані для формування Керівництва з льотної експлуатації літака.

Головні льотно-технічні характеристики сімейства літаків Ан-148-100/ Ан-158 (моделі Ан-148-100A, Ан-148-100B, Ан-148-100Е та Ан-158) наведені в таблиці. 
Головні льотно-технічні характеристики сімейства регіональних пасажирських літаків

\begin{tabular}{|c|c|c|c|c|c|}
\hline \multirow{2}{*}{$\begin{array}{l}\text { № } \\
\text { п/п }\end{array}$} & \multirow{2}{*}{ Найменування характеристики } & \multicolumn{4}{|c|}{$\begin{array}{c}\text { Сімейство літаків Ан-148-100/Ан-158 } \\
\text { Двигун Д-436-148Д }\end{array}$} \\
\hline & & $\begin{array}{c}\mathrm{AH}-148- \\
100 \mathrm{~A}\end{array}$ & $\begin{array}{l}\mathrm{AH}-148- \\
100 \mathrm{~B}\end{array}$ & $\begin{array}{l}\mathrm{AH}-148- \\
100 \mathrm{E}\end{array}$ & Ан-158 \\
\hline \multirow[t]{3}{*}{1} & \multicolumn{5}{|c|}{ Вага літака, кгс: } \\
\hline & - максимальна злітна & 38950 & 41950 & 43700 & 43700 \\
\hline & - максимальна посадкова & \multicolumn{3}{|c|}{37800} & 38800 \\
\hline 2 & $\begin{array}{l}\text { Максимальна вага комерційного } \\
\text { навантаження, кгс }\end{array}$ & \multicolumn{3}{|c|}{9000} & 9800 \\
\hline \multirow[t]{4}{*}{3} & \multicolumn{5}{|c|}{ Характеристики базування: } \\
\hline & - клас аеродрому & \multicolumn{4}{|c|}{$A, B, B$} \\
\hline & $\begin{array}{l}\text { - висота аеродрому над рівнем } \\
\text { моря, м }\end{array}$ & \multicolumn{4}{|c|}{ до 2200} \\
\hline & $\begin{array}{l}\text { - стан штучної ЗПС (ШЗПС) } \\
\quad(\mu \geq 0,3)\end{array}$ & \multicolumn{4}{|c|}{$\begin{array}{l}\text { - суха, волога, мокра; } \\
\text { - } \text { з окремими ділянками стоячої води; } \\
\text { - покрита інієм або намороззю; } \\
\text { - покрита шаром сльоти до } 15 \text { мм; } \\
\text { - } \\
\text { з шаром сухого снігу - товщиною } \\
\text { не більше } 50 \text { мм; } \\
\text { - } 3 \text { шаром мокрого снігу - товщиною } \\
\text { не більше } 50 \text { мм }\end{array}$} \\
\hline \multirow[t]{4}{*}{4} & \multicolumn{5}{|c|}{ Злітні характеристики (ШЗПС, $\mu \geq 0,6, \mathrm{CA}, \mathrm{H}=0$, штиль, $\left.\delta_{\text {закр }}=20^{\circ}\right)$ : } \\
\hline & - довжина розбігу, м & 1050 & 1235 & 1335 & 1335 \\
\hline & - злітна дистанція до Н = 10,7 м, м & 1365 & 1595 & 1725 & 1750 \\
\hline & $\begin{array}{c}\text { - збалансована дистанція зльоту } \\
\text { (кінцева смуга гальмування } \\
\text { КСГ }=400 \text { м), м } \\
\end{array}$ & 1485 & 1730 & 1885 & 1900 \\
\hline \multirow[t]{6}{*}{5} & \multicolumn{5}{|c|}{ Характеристики польоту за маршрутом: } \\
\hline & Максимальна висота польоту, м & & 12200 & & 11580 \\
\hline & Крейсерські висоти польоту, м & & $100 \ldots 12$ & & $\begin{array}{l}10100 \ldots \\
\ldots 11580\end{array}$ \\
\hline & $\begin{array}{l}\text { Максимальна крейсерська } \\
\text { швидкість польоту (режим роботи } \\
\text { двигунів МП, Н=10100 м), км/год } \\
\text { ІШ (істинна швидкість) }\end{array}$ & \multicolumn{4}{|c|}{870} \\
\hline & $\begin{array}{l}\text { Крейсерська швидкість на } \\
\text { крейсерському режимі роботи } \\
\text { двигунів, км/год ІШ }\end{array}$ & \multicolumn{4}{|c|}{$800 \ldots 850$} \\
\hline & $\begin{array}{l}\text { Годинні витрати палива на крей- } \\
\text { серських висотах і швидкостях, } \\
\text { км/год }\end{array}$ & $\begin{array}{l}1640 \ldots \\
\ldots 1510\end{array}$ & $\begin{array}{l}1760 \ldots \\
\ldots 1510\end{array}$ & $\begin{array}{l}1840 \ldots \\
\ldots 1510\end{array}$ & $\begin{array}{l}1840 \ldots \\
\ldots 1560\end{array}$ \\
\hline
\end{tabular}


Закінчення таблиці

\begin{tabular}{|c|c|c|c|c|c|}
\hline \multirow{2}{*}{$\begin{array}{l}\text { № } \\
\Pi / \Pi\end{array}$} & \multirow{2}{*}{ Найменування характеристики } & \multicolumn{4}{|c|}{$\begin{array}{c}\text { Сімейство літаків Ан-148-100/Ан-158 } \\
\text { Двигун Д-436-148Д }\end{array}$} \\
\hline & & $\begin{array}{l}\mathrm{AH}-148- \\
100 \mathrm{~A}\end{array}$ & $\begin{array}{l}\mathrm{AH}-148- \\
100 \mathrm{~B}\end{array}$ & $\begin{array}{l}\text { Ан-148- } \\
100 E\end{array}$ & Ан-158 \\
\hline & \multicolumn{5}{|c|}{ Практична дальність ( $G_{3 л \text { max }} ; H_{\text {найв }} ; V_{\text {найв }} ;$ АНЗ палива - 1300 кг), км: } \\
\hline & • з максимальним навантаженням & $\begin{array}{c}1240 \\
(9000 \mathrm{kг \textrm {C }}) \\
\end{array}$ & $\begin{array}{c}2570 \\
(9000 \text { кгс }) \\
\end{array}$ & $\begin{array}{c}3290 \\
(9000 \text { кгс })\end{array}$ & $\begin{array}{c}2270 \\
(9800 \text { кгс }) \\
\end{array}$ \\
\hline & \multirow[t]{2}{*}{ • з пасажирами *) } & $\begin{array}{c}1940 \\
(80 \text { пас.) } \\
\end{array}$ & $\begin{array}{c}3280 \\
(80 \text { пас. }) \\
\end{array}$ & $\begin{array}{c}3990 \\
(80 \text { пас. }) \\
\end{array}$ & $\begin{array}{c}2460 \\
(99 \text { пас.) } \\
\end{array}$ \\
\hline & & $\begin{array}{c}2180 \\
(75 \text { пас.) }\end{array}$ & $\begin{array}{l}3520 \\
(75 \text { пас.) }\end{array}$ & $\begin{array}{c}4240 \\
(75 \text { пас.) }\end{array}$ & $\begin{array}{c}2930 \\
(89 \text { пас.) }\end{array}$ \\
\hline & $\begin{array}{l}\text { • } 3 \text { максимальною заправкою } \\
\text { «під обріз»/кількість пасажирів* }\end{array}$ & $5220 / 16$ & $4890 / 47$ & $4700 / 65$ & $\begin{array}{c}4110^{* *} / \\
64\end{array}$ \\
\hline & • перегінна дальність & \multicolumn{3}{|c|}{5460} & $\begin{array}{l}4880 \\
\mathrm{AH3}^{* *}\end{array}$ \\
\hline & $\begin{array}{l}\text { Технічна дальність, км: } \\
\text { • з N пасажирами; }\end{array}$ & $2860 / 75$ & $4200 / 75$ & $4920 / 75$ & $3310 / 99$ \\
\hline & $\begin{array}{l}\text { - максимальна заправка/ } \\
\text { кількість пасажирів }\end{array}$ & 5 970/16 & 5 600/47 & 5 400/65 & $4950 / 64$ \\
\hline & Паливна ефрективність, г/пас×км & $\begin{array}{c}28,04 \\
(80 \text { пас.) }\end{array}$ & $\begin{array}{c}27,73 \\
(80 \text { пас.) }\end{array}$ & $\begin{array}{c}28,03 \\
(80 \text { пас.) }\end{array}$ & $\begin{array}{c}24,65 \\
(99 \text { пас.) }\end{array}$ \\
\hline
\end{tabular}

6. Посадкові характеристики (ШЗПС; $\mu \geq 0,6 ; H_{a e p}=0 ;$ СА; штиль; глісада $\theta=-3^{\circ} 40^{\prime} ;$ конфрігурація крила $\left.\delta_{\text {закр }}=40^{\circ}\right)$ :

\begin{tabular}{|l|c|c|}
\hline довжина розбігу, м & 765 & 795 \\
\hline необхідна довжина ШЗПС, м & 1950 & 2045 \\
\hline
\end{tabular}

*) - вага одного пасажира з багажем прийнята такою, що дорівнює 95 кгс;

${ }^{* *}$ - АНЗ палива на 1 годину польоту на висоті кола над аеродромом.

Відповідність характеристик стійкості, керованості та динаміки польоту сімейства літаків Ан-148-100/Ан-158 нормам льотної придатності АП-25 для штатного фрункціонування ЕДСК продемонстровано розрахунками, а також дослідженнями, проведеними на дослідно-пілотажному стенді сімейства літаків Ан-148-100/Ан-158 (ДПС-148). Характеристики стійкості, керованості та динаміки польоту літака у відмовних ситуаціях досліджені за допомогою розрахунку та дослідно-пілотажного стенда.

Розрахунок характеристик стійкості та керованості літака, математичне моделювання динаміки польоту та синтез алгоритмів системи керування виконувалися 3 використанням спеціалізованого програмного забезпечення, розробленого ДП «АНТОНОВ».

У процесі льотних випробувань літака було виконано незначну корекцію алгоритмів роботи ЕДСК.

Отже, сертифрікаційні льотні випробування сімейства літаків Ан-148-100/ 
Ан-158 підтвердили повну відповідність характеристик їх стійкості, керованості та динаміки польоту вимогам сертифікаційного базису як для штатних, так і для відмовних ситуацій, винесених на льотні випробування.

Літаки як об'єкти керування в штатних і відмовних ситуаціях отримали високу оцінку пілотів, що є важливим чинником при формуванні замовлень на ці літаки потенційними експлуатантами.

Нижче наведено перелік технічних звітів, інженерних аналізів і технічних довідок із аеродинаміки, ЛТХ, ЗПХ стійкості, керованості та динаміці польоту літаків сімейства Ан-148-100/Ан-158:

- Літак Ан-148-100. Аеродинаміка. Книга 1. Льотні характеристики. Частина 1. Вихідні дані аеродинамічного розрахунку. Технічний звіт.

- Літак Ан-148-100. Аеродинаміка. Книга 1. Льотні характеристики. Частина 2. Злітно-посадкові та маршрутні характеристики. Технічний звіт.

- Літак Ан-148-100. Аеродинаміка. Книга 1. Льотні характеристики. Частина 5. Розрахунок шкідливого аеродинамічного опору. Технічний звіт.

- Літак Ан-148-100. Аеродинаміка. Книга 2. Стійкість, керованість і динаміка польоту. Частина 1. Вихідні дані для розрахунку характеристик стійкості, керованості та динаміки польоту. Технічний звіт.

- Літак Ан-148-100. Аеродинаміка. Книга 2. Стійкість, керованість і динаміка польоту. Частина 2. Характеристики стійкості, керованості та динаміки польоту. Технічний звіт.

- Літак Ан-148-100. Аеродинаміка. Книга 2. Стійкість, керованість та динаміка польоту. Частина 3. Характеристики стійкості та керованості на режимах звалювання, штопора та післяштопорного пікірування. Технічний звіт.

- Літак Ан-148-100. Характеристики стійкості та керованості при відриві маршової силової установки. Інженерний аналіз.

- Літак Ан-148-100. Обґрунтування можливості зняття протиобліднювальної системи з горизонтального оперення за умови забезпечення необхідних характеристик поздовжньої стійкості та керованості. Інженерний аналіз.

- Літак Ан-148-100 (моделі Ан-148-100А, Ан-148-100В,Ан-148-100Е). Аеродинамічні характеристики. Частина 1. Вихідні дані розрахунку льотних характеристик. Інженерний аналіз.

- Літак Ан-148-100 (моделі Ан-148-100A, Ан-148-100B, Ан-148-100E). Аеродинамічні характеристики. Частина 2. Вихідні дані розрахунку характеристик стійкості, керованості та динаміки польоту. Інженерний аналіз.

- Літак Ан-148-100 (моделі Ан-148-100A, Ан-148-100B, Ан-148-100Е). Льотні характеристики в очікуваних умовах експлуатації. Інженерний аналіз.

- Літак Ан-148-100 (моделі Ан-148-100А, Ан-148-100В, Ан-148-100Е). Критичний проміжок часу при відмові двигуна і автоматичної системи керування двигуном. Технічна довідка.

- Літак Ан-148-100 (моделі Ан-148-100A, Ан-148-100В, Ан-148-100Е). Відповідність літака з обладнанням TCAS-2000 вимогам СТУ/148F.1.1.3.18,19 СБ-148: ЛЬОТНІ ХАРАКТЕРИСТИКИ. Інженерний аналіз.

- Літак Ан-148-100 (моделі Ан-148-100А, Ан-148-100B, Ан-148-100Е). Характеристики стійкості та керованості В умовах природного обледеніння. Інженерний аналіз.

- Літак Ан-148-100. Аеродинаміка. Основні результати аеродинамічного 
проектування, трубних і льотних випробувань (1999-2005 рр.). Технічний звіт.

- Літак Ан-148-100 (моделі Ан-148-100А, Ан-148-100В, Ан-148-100Е). Коефіцієнт тертя при гальмуванні на мокрій штучній злітно-посадковій смузі. Інженерний аналіз.

- Літак Ан-148-100 (моделі Ан-148-100А, Ан-148-100В, Ан-148-100Е). Характеристики стійкості та керованості на штучній злітно-посадковій смузі, вкритій атмосферними опадами. Інженерний аналіз.

- Літак Ан-148-100 (моделі Ан-148-100А, Ан-148-100B, Ан-148-100Е). Льотні характеристики в умовах обледеніння. Інженерний аналіз.

- Літак Ан-148-100 (моделі Ан-148-100А, Ан-148-100В, Ан-148-100Е). Злітно-посадкові характеристики на штучних злітно-посадкових смугах, вкритих атмосферними опадами. Інженерний аналіз.

- Літак Ан-148-100 (моделі Ан-148-100А, Ан-148-100В, Ан-148-100Е). Розрахункова швидкість пікірування. Швидкісні характеристики. Характеристики літака при розбалансуванні. Інженерний аналіз.

- Літак Ан-148-100. Характеристики стійкості та керованості при відмовах функціональних систем. Технічний звіт.

- Літак Ан-148-100. (моделі Ан-148-100А, Ан-148-100B, Ан-148-100Е). Мінімальні еволютивні швидкості розбігу, зльоту та посадки. Інженерний аналіз.

- Літак Ан-148-100. Порівняння збіжності розрахункових та експериментальних вихідних траєкторій зльоту та посадки для сертифікації щодо шуму на місцевості. Технічна довідка.

- Літак Ан-148-100 (моделі Ан-148-100А, Ан-148-100В, Ан-148-100Е). Розрахунок рівня повітрообміну В пожежонебезпечних зонах хвостового оперення. Технічна довідка.

- Літак Ан-148-100 (моделі Ан-148-100A, Ан-148-100В, Ан-148-100Е). Оцінка ступеня небезпеки ситуації при руйнуванні агрегатів. Інженерний аналіз.

- Літак Ан-148-100 (моделі Ан-148-100A, Ан-148-100B, Ан-148-100Е). Льотні характеристики при відмовах функціональних систем. Інженерний аналіз.

- Літак Ан-148-100 (моделі Ан-148-100А, Ан-148-100В, Ан-148-100E). Відповідність вимозі 25.1001(а) СБ-148: система аварійного зливу палива. Технічна довідка.

- Літак Ан-148-100 (моделі Ан-148-100А, Ан-148-100В, Ан-148-100Е). Остійність та плавучість при аварійній посадці на воду. Технічний звіт. Обчислювальна система літаководіння ВСС-100. Льотно-технічні характеристики літака АН-148-100 (моделі Ан-148-100А, Ан-148-100B, Ан-148-100Е). Технічний звіт.

- Літак Ан-148-100 (моделі Ан-148-100А, Ан-148-100В, Ан-148-100Е). Льотні характеристики в очікуваних умовах експлуатації зі збільшеними злітною вагою та збільшеною вагою без палива. Інженерний аналіз.

- Літак Ан-148-100 (моделі Ан-148-100А, Ан-148-100B, Ан-148-100Е). Характеристики стійкості та керованості на посадці. Інженерний аналіз.

- Літак Ан-148-100 (моделі Ан-148-100А, Ан-148-100B, Ан-148-100Е). Розрахунок максимально допустимої швидкості вітру при рулюванні. Інженерний аналіз.

- Літак Ан-148-100 (моделі Ан-148-100А, Ан-148-100В, Ан-148-100Е). 
Злітно-посадкові характеристики та характеристики стійкості і керованості при експлуатації на ґрунтових ЗПС. Інженерний аналіз.

- Літак Ан-148-100 (моделі Ан-148-100А, Ан-148-100B, Ан-148-100Е). Визначення впливу відхилень конфігурацій зовнішньої поверхні по проекту «configurationdeviationlist» на аеродинамічні та льотні характеристики літака. Інженерний аналіз.

- Літак Ан-148-100 (моделі Ан-148-100А, Ан-148-100B, Ан-148-100Е, Ан-158). Визначення відповідності вимогам СБ-148 за льотними характеристиками, характеристиками стійкості та керованості у зв'язку з введенням Головної зміни в типову конструкцію «Збільшення висоти аеродромного базування». Інженерний аналіз.

- Літак Ан-148-100 (моделі Ан-148-100А, Ан-148-100В, Ан-148-100Е). Злітно-посадкові характеристики з відключеною гальмівною системою одного колеса та відмовою в гальмівній системі одного стояка ГОШ. Інженерний аналіз.

- Літак Ан-148-100 (моделі Ан-148-100А, Ан-148-100В, Ан-148-100Е). Визначення відповідності вимогам СБ-148 за льотними характеристиками, характеристиками стійкості та керованості у зв'язку з введенням Головної зміни в типову конструкцію «Збільшення максимальної посадкової ваги до 37800 кгс». Інженерний аналіз.

- Літак Ан-148-100 (моделі Ан-148-100А, Ан-148-100В, Ан-148-100Е). Злітні характеристики літака на штучних злітно-посадкових смугах, покритих атмосфрерними опадами, при $\mathrm{V}_{1}<\mathrm{V}_{\mathrm{R}}$. Інженерний аналіз.

- Літак Ан-148-100 (моделі Ан-148-100A, Ан-148-100В, Ан-148-100Е). Оцінка наслідків відмови функціональних систем літака у зв'язку 3 головною зміною «Збільшення максимальної посадкової ваги до 37800 кгс» (режим штурвального управління). Інженерний аналіз.

- Літак Ан-148-100 (моделі Ан-148-100А, Ан-148-100В, Ан-148-100Е). Льотні характеристики літака при виконанні польоту з випущеними шасі. Інженерний аналіз.

- Літак Ан-148-100В. Льотні характеристики зі збільшеною максимальною злітною вагою до 42,55 тс. Інженерний аналіз.

- Літак Ан-158. Вихідні дані розрахунку льотних характеристик. Науковотехнічний звіт. Літак Ан-158. Льотні характеристики. Науково- технічний звіт.

- Літак Ан-158. Характеристики стійкості, керованості та динаміки польоту. Науково-технічний звіт.

- Порівняння характеристик стійкості, керованості та динаміки польоту літаків Ан-158 і Ан-148-100 за результатами льотних випробувань на режимах, які використовують при заході на посадку за I, II та IIIA категоріями IКАО. Науково-технічний звіт.

- Літак Ан-158. Плавучість та остійність при аварійній посадці на воду. Інженерний аналіз.

- Літак Ан-158. Стійкість, керованість та динаміка польоту. Інженерний аналіз.

- Літак Ан-158. Льотні характеристики. Інженерний аналіз.

- Літак Ан-158. Аеродинамічні характеристики за результатами льотних випробувань. Інженерний аналіз.

- Літак Ан-158. Порівнювальний аналіз аеродинамічних характеристик 
літаків Ан-158 і Ан-148-100 для оцінювання наслідків відмов фрункціональних систем літака Ан-158. Інженерний аналіз.

- Літак Ан-158. Обчислювальна система літаководіння BВC-100. Льотнотехнічні характеристики. Технічний звіт.

- Літак типу Ан-148-100 (модель Ан-158). Визначення відповідності вимогам СБ-148 за льотними характеристиками, характеристиками стійкості та керованості у зв'язку з введенням Головної зміни в типову конструкцію: «Збільшення максимальної посадкової ваги до 38800 кгс». Інженерний аналіз.

- Літак Ан-158. Льотні характеристики літака при виконанні польоту з шасі, що не прибирається. Інженерний аналіз.

- Літак Ан-148-100 (моделі Ан-148-100A, Ан-148-100B, Ан-148-100Е та Ан-158). Відповідність літака вимогам СБ-148 за характеристиками зльоту в зв'язку з внесенням Головної зміни типової конструкції: «Виконання зльоту на режимі роботи двигунів менше злітного». Інженерний аналіз.

- Літаки Ан-148-100, Ан-148-200, Ан-158. Визначення відповідності вимогам СБ-148 за льотними характеристиками, характеристиками стійкості та керованості у зв'язку з введенням Головної зміни в типову конструкцію: «Збільшення висоти аеродромного базування понад 2200 м». Інженерний аналіз.

Всі ці технічні звіти, інженерні аналізи та технічні довідки входять до переліку необхідної доказової документації при подальшій сертифікації літака

\section{Експериментальні аеродинамічні дослідження}

Експериментальні аеродинамічні дослідження $€$ важливим етапом розроблення аеродинамічного компонування сімейства літаків Ан-148-100/Ан-158 та визначення їх аеродинамічних характеристик, необхідних для виконання розрахунку льотних характеристик, а також характеристик стійкості, керованості та динаміки польоту.

Експериментальні аеродинамічні дослідження сімейства літаків Ан-148-100/Ан-158 проведені в таких аеродинамічних трубах (АДТ):

- дозвукова АДТ АТ-1 ДП «АНТОНОВ»;

- трансзвукова АДТ Т-106М ЦАГІ (Російська Федерація).

АТ-1 - дозвукова аеродинамічна труба замкнутого типу з відкритою робочою частиною. Швидкість потоку в робочій частині труби, при якій проводилися випробування моделей, становила $50 \mathrm{~m} / \mathrm{c}$.

В АТ-1 були проведені такі види випробувань:

- вагові випробування щодо визначення сумарних аеродинамічних характеристик моделей літака як 3 макетами мотогондол, так і 3 імітаторами маршових двигунів;

- дренажні випробування щодо визначення розподілу тиску по поверхні агрегатів моделей;

- тензометричні випробування щодо визначення шарнірних моментів органів керування;

- фрізичні дослідження щодо візуалізації ліній течії і картин обтікання.

На рисунках 4 - 7 показано фотографії моделей літаків Ан-148-100 та Ан-158 у робочій частині АТ-1 при проведенні експериментів. 


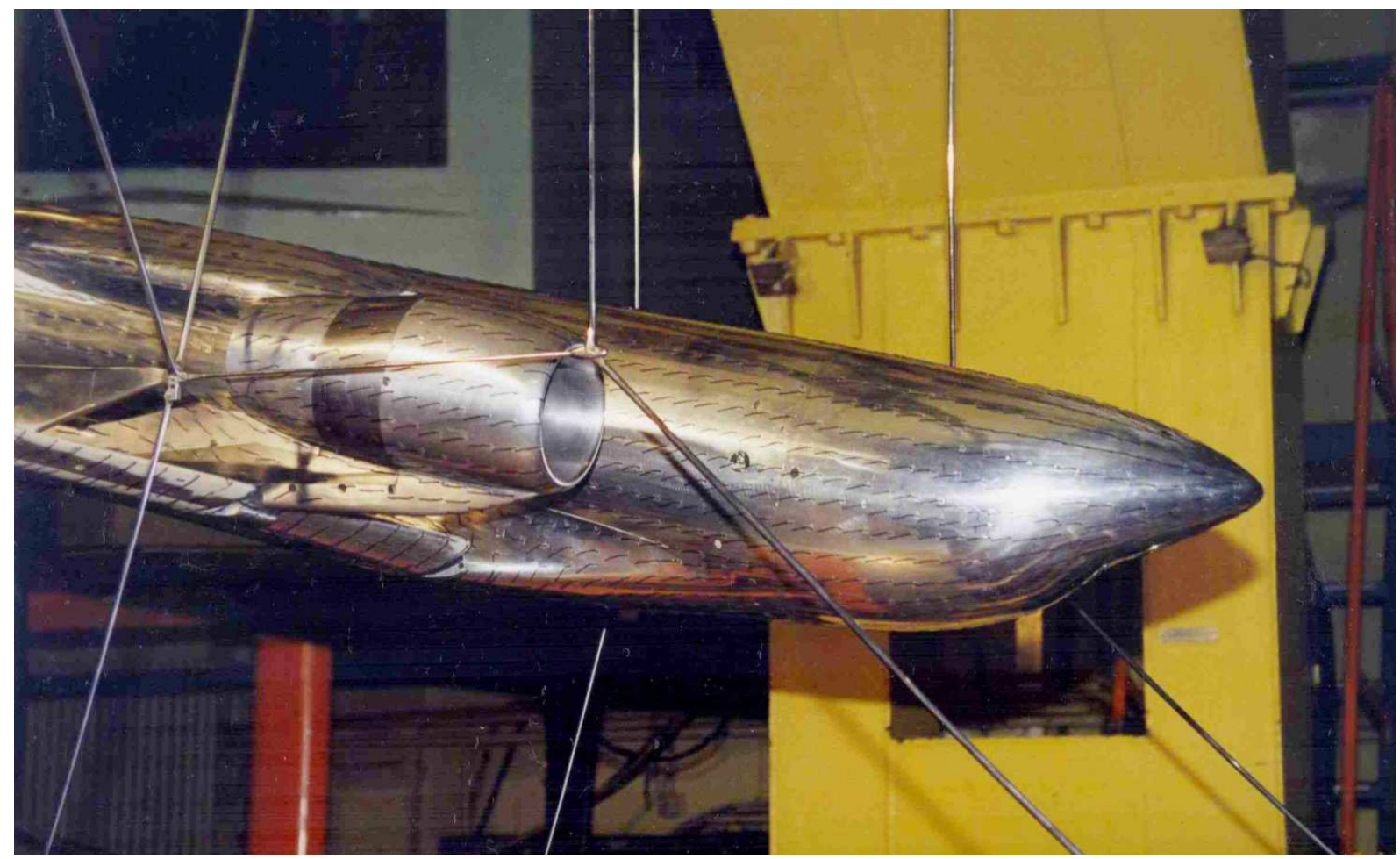

Рисунок 4 - Візуальні випробування моделі літака Ан-148 методом шовковинок в аеродинамічній трубі АТ-1

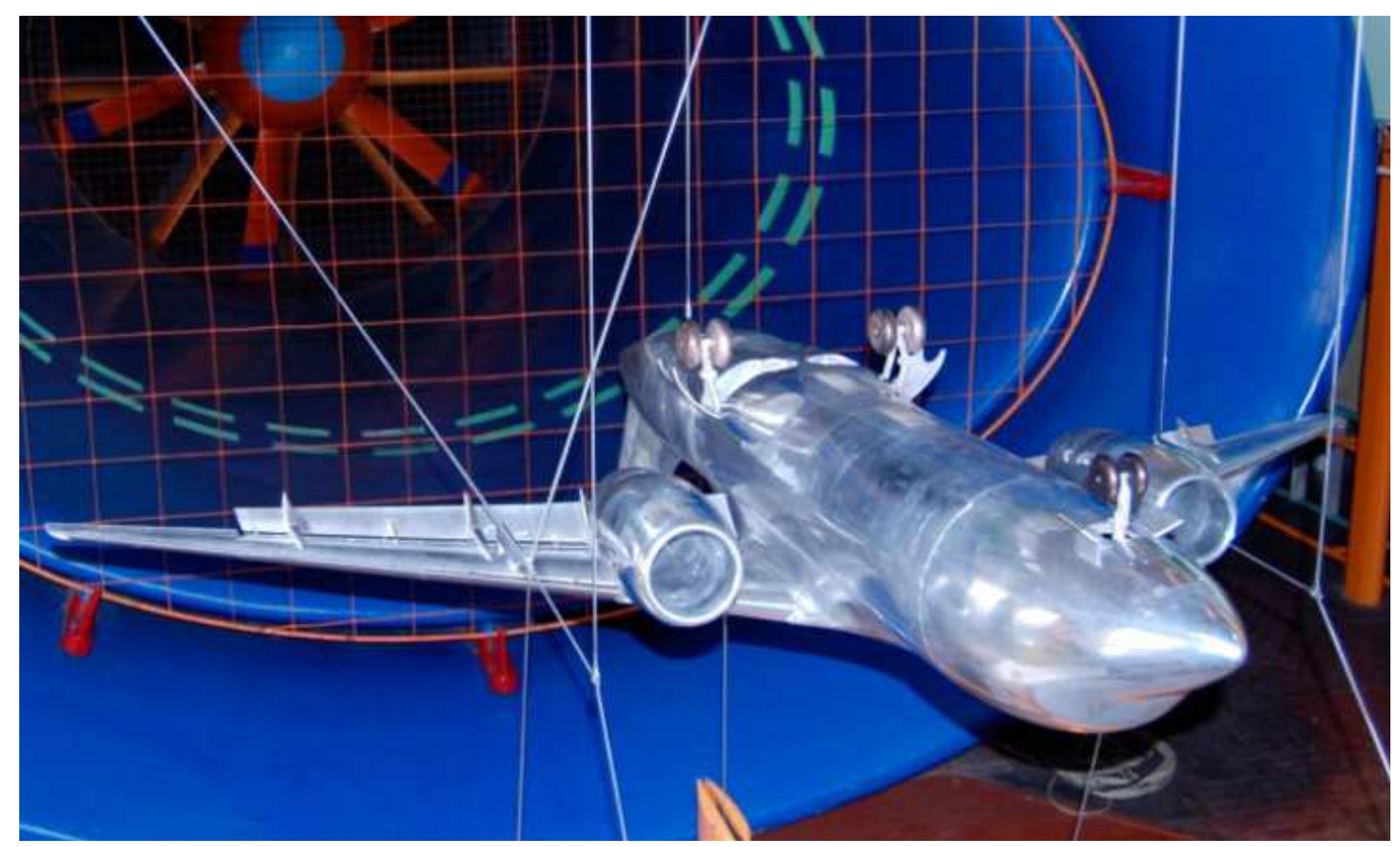

Рисунок 5 - Механізована модель літака Ан-148

в аеродинамічній трубі АТ-1 


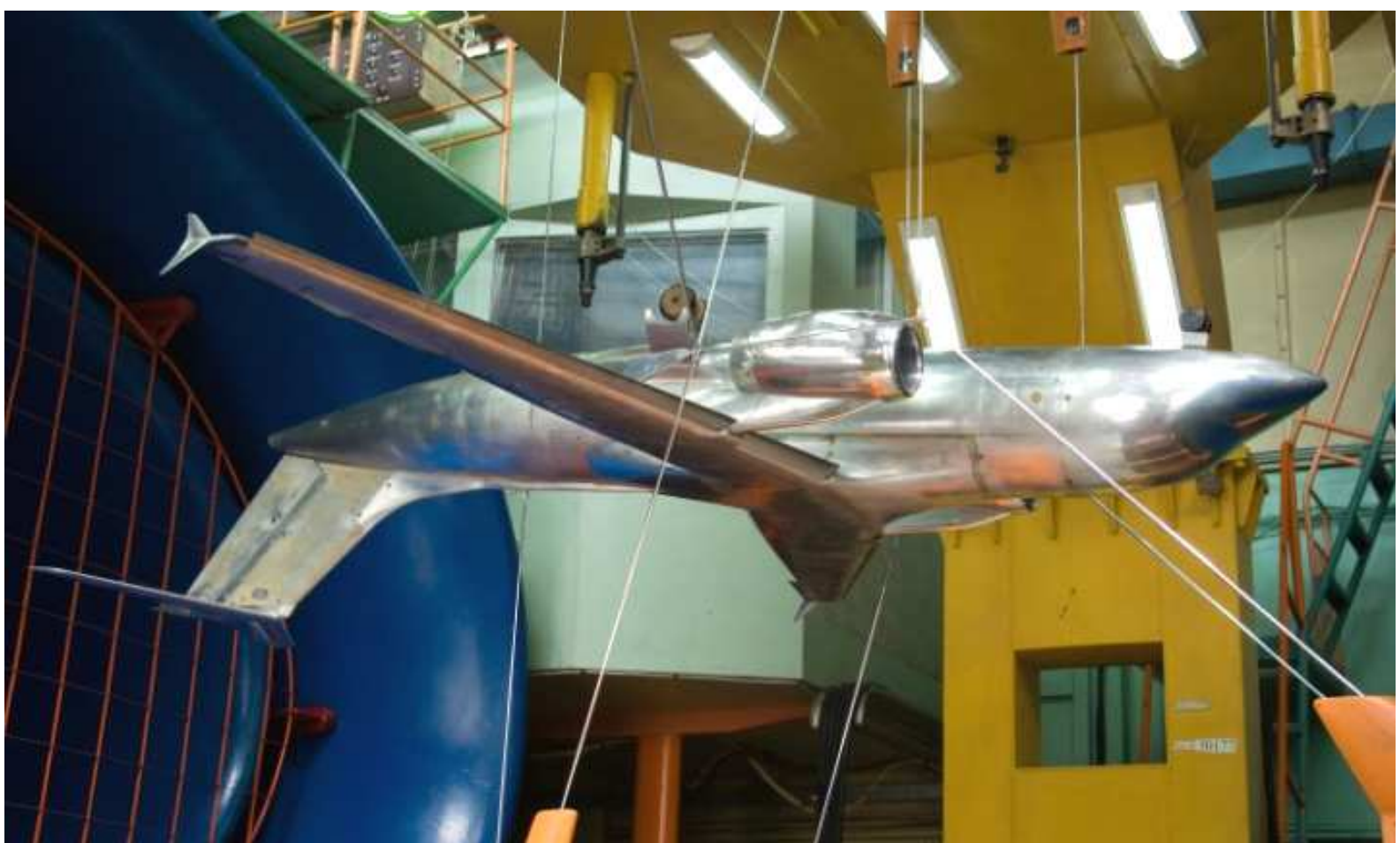

Рисунок 6 - Механізована модель літака Ан-158 в аеродинамічній трубі АТ-1

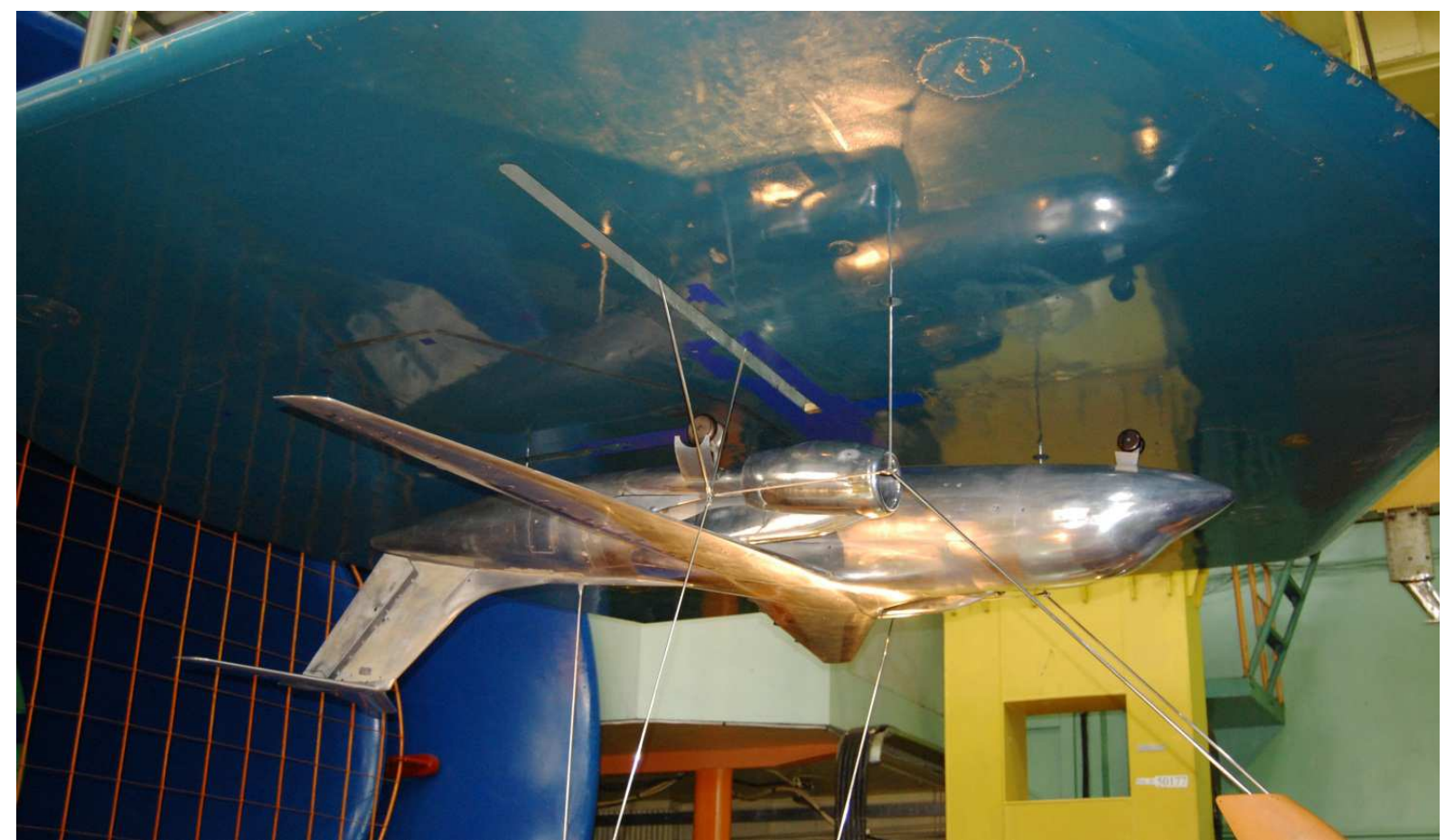

Рисунок 7 - Модель літака Ан-148 поблизу екрана в аеродинамічній трубі АТ-1

Т-106 - трансзвукова аеродинамічна труба замкненого типу безперервної дії і перемінної густини із закритою робочою частиною. Дослідження в цій АДТ дозволили визначити вплив стискання за числом Маха (число М) і товщини примежового шару за числом Рейнольдса (число $R e$ ) на аеродинамічні 
характеристики літака.

Швидкість потоку в робочій частині труби змінювалася в діапазоні чисел $M=0,15 \ldots 0,9$, а число $R e$ - у діапазоні $1,51 \cdot 10^{6} \ldots 7,1 \cdot 10^{6}$ залежно від виду випробувань.

В АДТ Т-106М ЦАГІ проводилися такі види випробувань:

- визначення сумарних аеродинамічних характеристик моделей на електромеханічних і тензометричних вагах;

- вимірювання розподілу тиску по поверхні моделі електронними модулями тисків;

- фрізичні дослідження щодо візуалізації ліній течій і картин обтікання.

На рисунках 8-10 показані фотографрії моделей літака Ан-148-100 в робочій частині Т-106М ЦАГІ при проведенні експериментів.

Злітно-посадкові режими польоту літака були досліджені в АДТ АТ-1 на моделях:

- 03МС148.001 - повна механізована модель літака з макетами мотогондол і з імітаторами маршових двигунів у масштабі М 1:12;

- 10МОК148.001 - механізований відсік крила з хордою $b=0,5 м$ і двома дренажними перерізами;

- 08ПМК148.001 - механізована модель консолі крила літака в масштабі М 1:6 з тензометрованими інтерцепторами і елероном;

- 04МХ0148.001 - модель ізольованого хвостового оперення літака в масштабі М 1:5 з тензометрованими рулями висоти і напрямку.

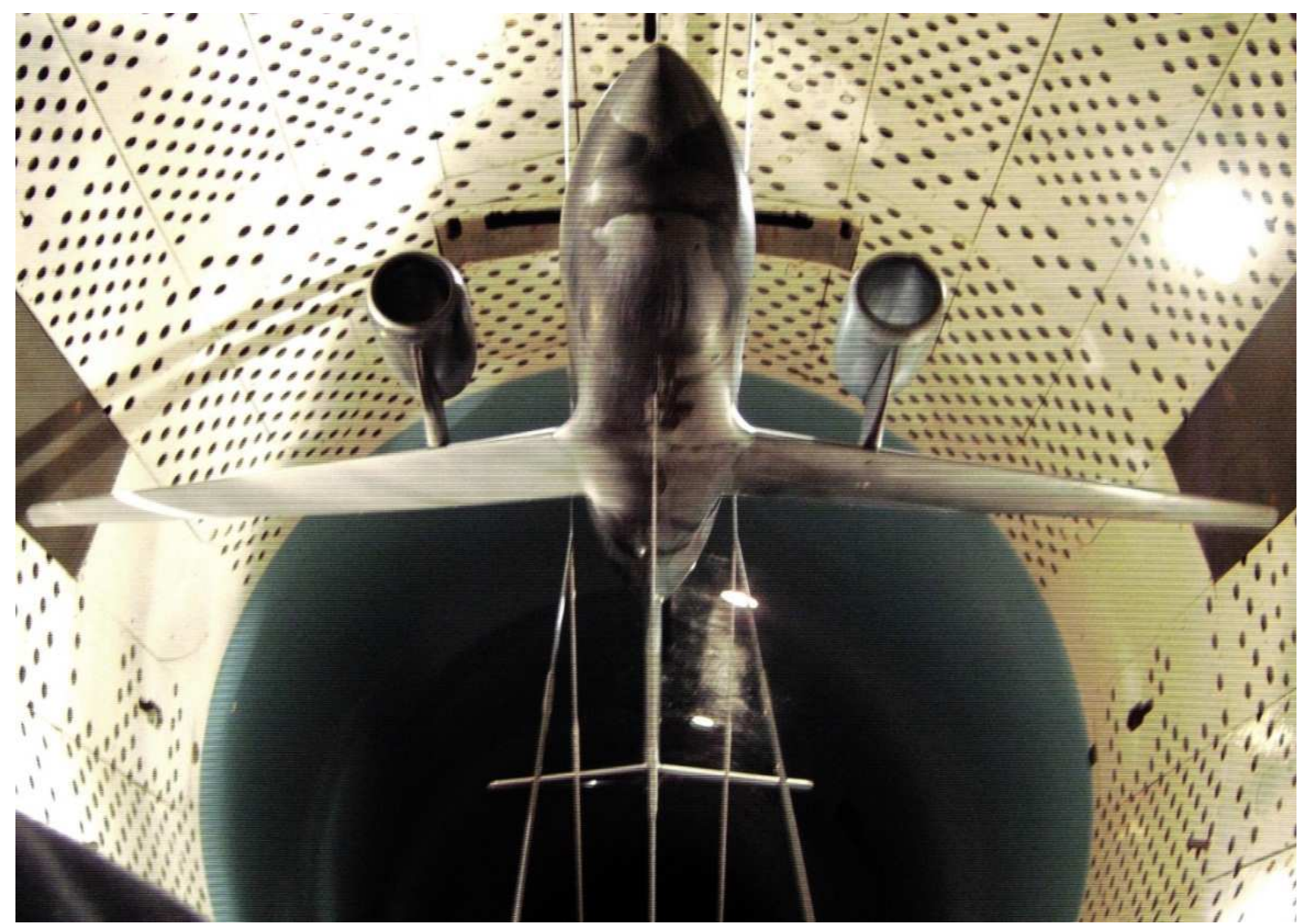

Рисунок 8 - Модель літака Ан-148-100 в робочій частині АДТ Т-106М ЦАГІ. Вагові випробування 


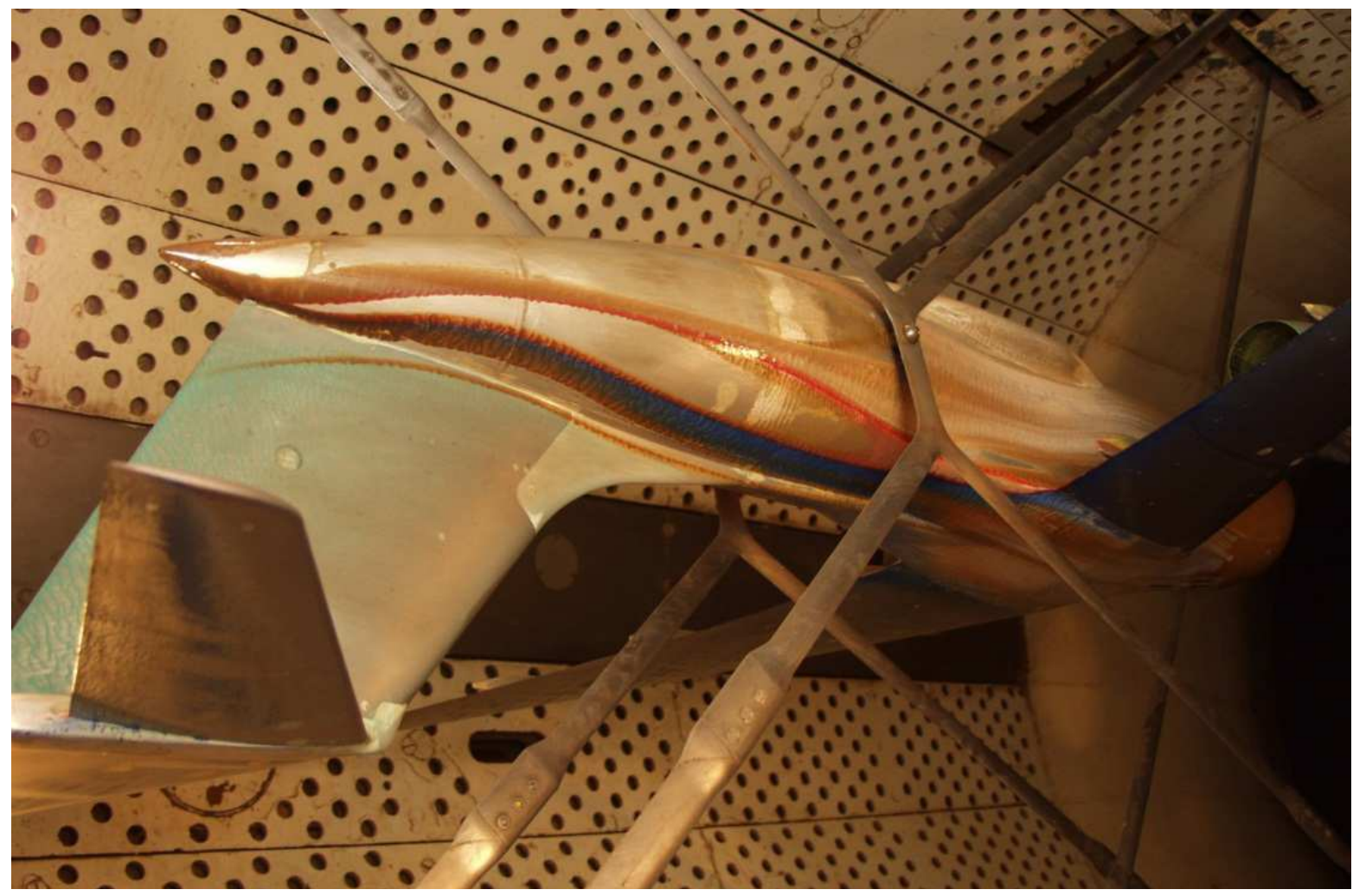

Рисунок 9 - Фізичні дослідження обтікання моделі

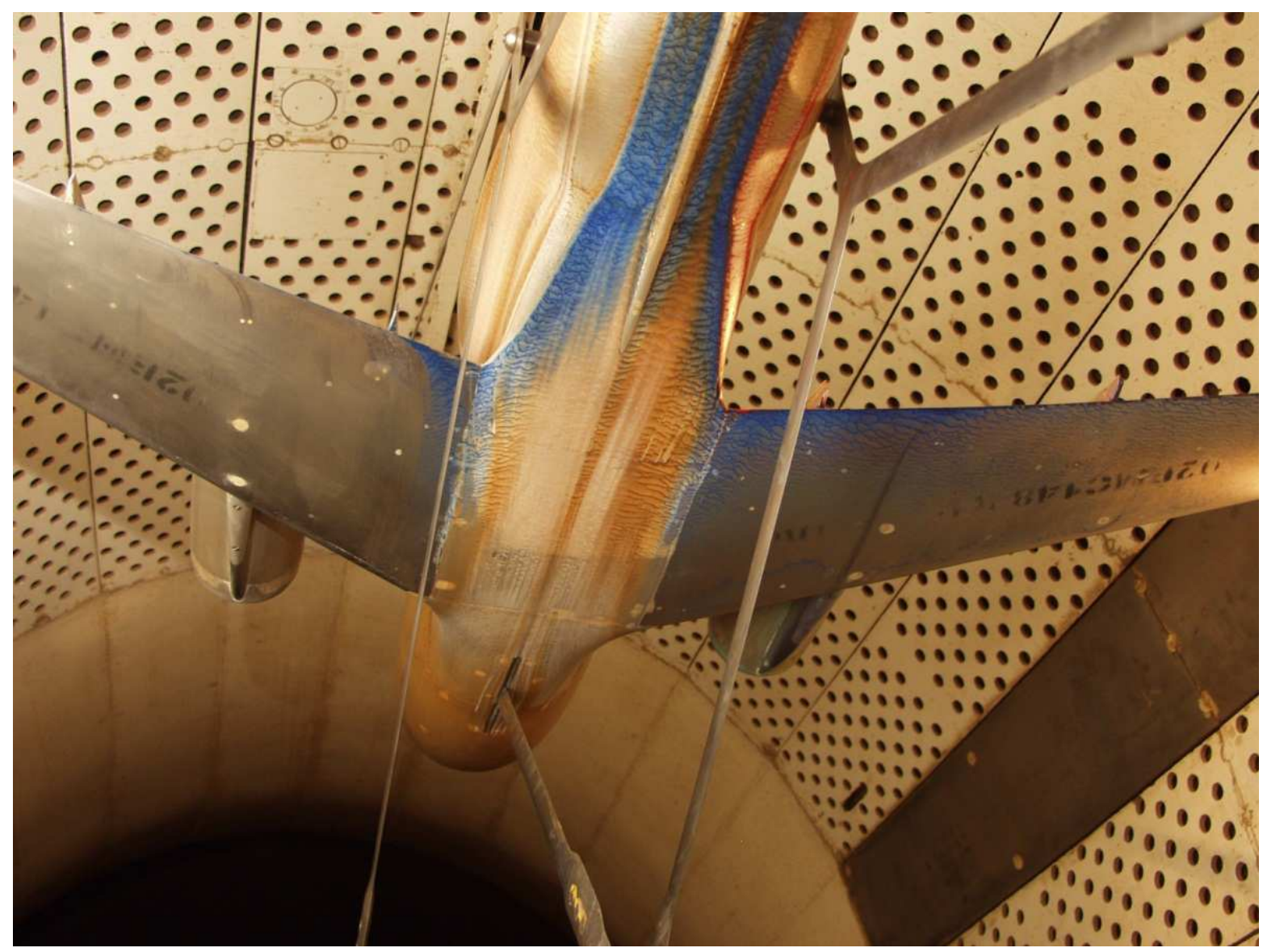

Рисунок 10 - Фізичні дослідження обтікання моделі 
Дослідження крейсерських режимів польоту літака і відпрацювання його аеродинамічного компонування виконані в АДТ Т-106 на моделях:

- 002(Б,В,И)МС148.106 - повна модель літака в крейсерській конфігурації в масштабі М 1:16 і її модифрікації;

- 014МОК148.106 - профрільний відсік крила з хордою b=0,3м і одним дренажним перерізом;

- 007МС148.106 - повна дренована модель літака в крейсерській конфрігурації в масштабі М 1:16.

Характеристики штопора літака і вихід з нього досліджені в аеродинамічній трубі Т-105 ЦАГІ на моделі 005МС148.105, виконаній в масштабі М 1:25.

Для досліджень аварійної посадки літака на воду були проведені випробування моделі 006КМС148.ГК на стенді гідродинамічної лабораторії ЦАГІ.

Моделі літаків для всіх видів випробувань в аеродинамічних трубах спроектовані і виготовлені на ДП «АНТОНОВ».

Загальний обсяг випробувань моделей в АДТ АТ-1 становив 3800 трубогодин, а в АДТ Т-106 - 3350 трубогодин.

Отримані матеріали експериментальних робіт щодо аеродинамічних досліджень використовувались для доводки аеродинамічного компонування літака в цілому і окремих його агрегатів.

Нижче наведено перелік звітів із дослідження аеродинамічних характеристик літака Ан-148 на моделях в аеродинамічній трубі АТ-1 ДП «АНТОНОВ»:

- Дослідження в аеродинамічній трубі АТ-1 моделі літака Ан-148 (02БМС 148.106) щодо доводки місцевої аеродинаміки. Звіт.

- Результати експериментальних і розрахункових досліджень щодо вибору попередніх місць встановлення плит прийому повітряного тиску на літаку Ан-148. Технічна довідка.

- Результати випробувань в аеродинамічній трубі АТ-1 моделі прямокутного відсіку середнього перерізу крила літака Ан-148 (10МОК148.001) щодо визначення ефрективності механізації. Звіт.

- Дослідження в аеродинамічній трубі АТ-1 ефективності двох типів реверсивних пристроїв на імітаторах двигунів моделі літака Ан-148. Звіт.

- Результати випробувань в аеродинамічній трубі АТ-1 моделі відсіку крила літака Ан-148 (10МОК148.001) щодо визначення впливу на ефективність передкрилка і закрилка параметрів їх встановлення. Звіт.

- Результати випробувань в аеродинамічній трубі АТ-1 виконавчої механізованої моделі літака Ан-148. Звіт.

- Результати випробувань в аеродинамічній трубі АТ-1 виконавчої моделі літака Ан-148 (03МС148.001) щодо визначення ефективності горизонтального оперення, руля висоти і руля напрямку. Звіт.

- Результати випробувань в аеродинамічній трубі АТ-1 виконавчої моделі літака Ан-148 щодо визначення ефективності елеронів та інтерцепторів. Звіт.

- Дослідження в аеродинамічній трубі АТ-1 моделі літака Ан-148 (03МС148.001) щодо усунення ділянки нестійкості за тангажем на докритичних кутах атаки в крейсерській конфігурації. Звіт.

- Результати випробувань в аеродинамічній трубі АТ-1 моделі 
хвостового оперення літака Ан-148 (04MX0148.001) щодо визначення аеродинамічних характеристик, ефективності руля висоти і руля напрямку та впливу імітаторів льоду на ГО і ВО. Звіт.

- Результати випробувань в аеродинамічній трубі АТ-1 моделі прямокутного механізованого відсіку крила літака Ан-148 (10МОК148.001) щодо визначення епюр розподілу тиску і оцінювання впливу імітатора льоду. Звіт.

- Результати випробувань в аеродинамічній трубі моделі літака Ан-148 (03MC148.001) щодо визначення шарнірних моментів елерона, ефрективності органів керування при закрилках, відхилених на $20^{\circ}$ i бокових аеродинамічних характеристик поблизу екрана. Технічна довідка.

- Результати візуальних випробувань в аеродинамічній трубі АТ-1 моделі літака Ан-148 (03МС148.001) щодо дослідження траєкторії руху відкидних дверей для аварійного покидання літака при заводських випробуваннях. Технічна довідка.

- Результати випробувань в аеродинамічній трубі АТ-1 моделі хвостового оперення літака Ан-148 (04MX0148.001) щодо визначення шарнірних моментів рулів висоти і напрямку і впливу імітаторів льоду. Звіт.

- Результати випробувань в АТ-1 моделі літака Ан-148 (03МС148.001) щодо визначення місцевих кутів атаки в області встановлення флюгерок датчиків кутів атаки. Звіт.

- Результати випробувань в аеродинамічній трубі АТ-1 моделі літака Ан148 (03МС148.001) щодо визначення аеродинамічних характеристик 3 імітаторами двигунів, які працюють на режимі прямої тяги і реверса. Звіт.

- Результати випробувань в аеродинамічній трубі АТ-1 моделі літака Ан-148 (03МС 148.001) щодо визначення ефективності секцій гальмівних інтерцепторів. Технічна довідка.

- Результати випробувань в аеродинамічній трубі АТ-1 моделі 03МС148.001 щодо визначення розподілу тиску по поверхні хвостової частини фюзеляжу і стулкам носової опори шасі. Технічна довідка.

- Результати випробувань в аеродинамічній трубі АТ-1 моделі літака Ан-148 щодо визначення аеродинамічних характеристик і ефективності органів керування на великих кутах атаки. Звіт.

- Результати випробувань в аеродинамічній трубі АТ-1 моделі літака Ан-148 (02Б.МС 148.106) щодо визначення ефективності вертикальних і горизонтальних аеродинамічних поверхонь крила. Технічна довідка.

- Результати випробувань в аеродинамічній трубі АТ-1 моделі відсіку крила літака Ан-148 (010МОК148.001) щодо оцінювання впливу імітаторів льоду, які відповідають льодоутворенню при відмові ПОС, на аеродинамічні характеристики. Технічна довідка.

- Результати випробувань в аеродинамічній трубі АТ-1 моделі літака Ан-148 щодо оцінювання впливу щитків на обтікання кришки-щита нижнього аварійного люка. Технічна довідка.

- Результати випробувань моделі літака Ан-148 (03MC148.001) щодо визначення впливу імітатора льоду на носовій частині фюзеляжу на аеродинамічні характеристики, місцеві кути атаки і величини повного 
і статичного тисків в області розміщення приймачів бортових засобів вимірювання. Технічна довідка.

- Результати випробувань в аеродинамічній трубі АТ-1 моделі літака Ан-148 (03MC148.001) щодо визначення впливу макета датчика зледеніння на місцеві кути атаки і на повний тиск у місцях встановлення ДАУ і ППД-1М. Технічна довідка.

- Результати випробувань в аеродинамічній трубі АТ-1 моделі літака Ан-148 (03МС148.001) щодо дослідження впливу вихорогенераторів на мотогондолах і перегородок на крилі. Звіт.

- Результати випробувань в аеродинамічній трубі АТ-1 моделі відсіку крила літака Ан-148 (10МОК148.001) щодо оцінювання впливу імітаторів льоду з різним виходом на верхню поверхню носка профрілю. Технічна довідка.

- Дослідження в аеродинамічній трубі АТ-1 щодо визначення опору макета заднього вузла системи підвіски двигуна Д-436 літака Ан-148. Технічна довідка.

- Результати випробувань в аеродинамічній трубі АТ-1 моделей літаків Ан-148 і Ан-74ТК-300 щодо дослідження шляхової стійкості і ефрективності вертикального оперення. Звіт.

- Результати випробувань в аеродинамічній трубі АТ-1 моделі ізольованого хвостового оперення літака Ан-148 (04MXO148.001) щодо визначення епюр розподілу тиску. Технічна довідка.

- Результати випробувань в аеродинамічній трубі АТ-1 дренованої моделі літака Ан-148 (07MC148.001) щодо визначення впливу тіл витіснення, встановлених у зоні сполучення пілона з крилом. Технічна довідка.

- Результати випробувань в аеродинамічній трубі АТ-1 моделі літака Ан-148 (03МС148.001) з імітаторами льоду на крилі. Технічна довідка.

- Результати випробувань в аеродинамічній трубі АТ-1 моделі літака Ан148 (03МС148.001) щодо збільшення піднімальної сили в посадковій конфрігурації. Звіт.

- Результати випробувань в аеродинамічній трубі АТ-1 моделі літака Ан-148 (03МС148.001) щодо визначення ефективності інтерцепторів для різних варіантів відхилення їх секцій. Технічна довідка.

- Дослідження в аеродинамічній трубі АТ-1 консольної частини крила літака Ан-148 (08ПМК148.001) щодо визначення впливу імітаторів льоду на аеродинамічні характеристики моделі і шарнірні моменти елерона та інтерцепторів. Науково-технічний звіт.

- Результати випробувань в аеродинамічній трубі АТ-1 моделі літака Ан-148 (03МС148.001) щодо дослідження течії займистих рідин із зон дренажу. Технічна довідка.

- Результати випробувань в аеродинамічній трубі АТ-1 моделі відсіку крила літака Ан-148 (10МОК148.001) щодо оцінювання впливу імітатора залишкового льоду, що утворюється на верхній поверхні крила за зоною обігріву. Технічна довідка.

- Результати випробувань в аеродинамічній трубі АТ-1 моделі літака Ан-148 щодо дослідження впливу вихорогенераторів, установлених на мотогондолах. Звіт.

- Результати випробувань в аеродинамічній трубі АТ-1 моделі 
консольної частини крила літака Ан-148 (08ПМК148.001) щодо визначення впливу кінцевої аеродинамічної поверхні ЗЦ6 на аеродинамічні поверхні моделі та шарнірні моменти елерона. Технічна довідка.

- Результати випробувань в аеродинамічній трубі АТ-1 моделі хвостового оперення літака Ан-148 (04MХO148.001) щодо визначення впливу імітатора льоду, що відповідає льодоутворенню за відсутності ПОС на горизонтальному оперенні. Технічна довідка.

- Дослідження в аеродинамічній трубі АТ-1 на моделі літака Ан-148 (03ИМС148.001) в посадковій конфігурації засобів запобігання звалюванню на крило. Науково-технічний звіт.

- Дослідження в аеродинамічній трубі АТ-1 на моделі 03КМС148.001 в посадковій конфігурації засобів уникнення звалювання на крило. Науково-технічний звіт.

- Результати випробувань в аеродинамічній трубі АТ-1 моделі літака Ан-148 (10МОК148.001) щодо оцінювання впливу генераторів вихорів на елементах механізації. Звіт.

- Результати вагових і дренажних випробувань в аеродинамічній трубі АТ-1 моделі прямокутного механізованого відсіку крила літака Ан-148 (10МОК148.001) щодо оцінювання впливу відхиленого інтерцептора на аеродинамічні характеристики моделі та на епюри розподілу тиску. Звіт. в ЦАГІ:

Перелік звітів щодо результатів випробувань моделей літака Ан-148-100

- Експрес-звіт. Результати експериментальних досліджень моделі 002.MC74-68.106 з крилом К20А в АДТ-106М.

- Експрес-звіт. Результати експериментальних досліджень моделі 002.МС74-68.106 з крилом К23 в АДТ-106М.

- Експрес-звіт. Результати експериментальних досліджень моделі 002.МC74-68.106 з крилом К21 в АДТ-106М.

- Експрес-звіт. Результати експериментальних досліджень моделі 002.МC74-68.106 з крилом К19А в АДТ-106М.

- Експрес-звіт. Результати додаткових експериментальних досліджень щодо вивчення впливу деяких елементів моделі 002.MC74-68.106 3 крилом К19А на аеродинамічні характеристики в АДТ-106М

- Експрес-звіт. Результати експериментальних досліджень щодо вивчення впливу носової частини (H3) і зализи крила $(Z 2)$ моделі 002.MC74-68.106 з крилом К19А на аеродинамічні характеристики в АДТ-106М.

- Експрес-звіт. Результати експериментальних досліджень щодо вивчення впливу зализів крила (Z2 та Z3t) моделі 002.MC74-68.106 з крилом К19А на аеродинамічні характеристики в АДТ-106М.

- Науково-технічний звіт. Результати експериментальних досліджень щодо вивчення впливу зализів крила (Z2Д, Z4, Z6), обтічника шасі ОШ5 та подовження циліндричної частини фюзеляжу на аеродинамічні характеристики моделі 002.МС74-68.106 з крилом К19-4 в АДТ-106М.

- Науково-технічний звіт. Результати експериментальних досліджень моделі 002ВМС148.106 з крилом К19-4А в АДТ-106М.

- Науково-технічний звіт. Результати експериментальних досліджень 
профрільованого відсіку 14МОК148.106 крила моделі літака Ан-148 в АДТ-106М.

- Звіт про науково-дослідну роботу. Попередній висновок про штопор літака Ан-148.

- Звіт. Додаток до попереднього висновку про штопор літака Ан-148.

- Візуальні дослідження попередньої моделі 002.MC74-68.106 літака Ан-148 в АДТ-106М ЦАГІ.

- Дослідження характеристик штопора моделі літака Ан-148 у вертикальній $\mathrm{a} / \mathrm{T}$ Т-105.

- Звіт. Результати випробувань виконавчої моделі літака Ан-148 в АДТ-106М ЦАГІ.

- Науково-технічний звіт. Дослідження посадки на воду моделі літака Ан-148.

- Експрес-звіт. Визначення розподілу тиску на крилі К19-4А, мотогондолі, пілоні, ОМЗ. Книга 1.1 (Крило - частина 1).

- Звіт про науково-дослідну роботу. Оброблення і аналіз результатів випробувань дренованої моделі літака Ан-148 в АДТ-106М ЦАГІ.

- Звіт. Аналіз результатів випробувань дренованої моделі літака Ан-148 на стрічковій підвісці в АДТ-106М ЦАГІ.

- Експрес-звіт. Визначення розподілу тиску на крилі К19-4А, мотогондолі, пілоні, ОМЗ. Книга 1.2 (Крило - частина 2).

- Експрес-звіт. Визначення розподілу тиску на крилі К19-4А, мотогондолі, пілоні, ОМЗ. Книга 1.5 (Обтічники механізмів закрилків - частина 1).

- Експрес-звіт. Визначення розподілу тиску на крилі К19-4А, мотогондолі, пілоні, ОМ3. Книга 1.6 (Обтічники механізмів закрилків - частина 2).

- Експрес-звіт. Визначення розподілу тиску на крилі К19-4А, мотогондолі, пілоні, ОМЗ. Книга 1.7 (Обтічники механізмів закрилків - частина 3).

- Звіт. Оброблення і аналіз результатів випробувань дренованої моделі літака Ан-148 в АДТ-106М ЦАГІ. Книга 1 (Крило-частина 1).

- Звіт. Оброблення і аналіз результатів випробувань дренованої моделі літака Ан-148 в АДТ-106М ЦАГІ. Книга 2 (Крило-частина 2).

- Звіт. Оброблення і аналіз результатів випробувань дренованої моделі літака Ан-148 в АДТ-106М ЦАГІ. Книга 3 (Горизонтальне оперення).

- Звіт. Експериментальні дослідження аеродинамічної моделі 002 МС148.106 літака Ан-148 в аеродинамічній трубі Т-106М 3 варіантами зализів і мотогондолою МГ-10.

- Експрес-звіт. Визначення розподілу тиску на фюзеляжі, ГО, ВО, обтічнику. Книга 2.1.а (фюзеляж - частина 1.а).

- Експрес-звіт. Визначення розподілу тиску на фюзеляжі, ГО, ВО, обтічнику. Книга 2.1.б (фюзеляж - частина 1.б).

- Експрес-звіт. Визначення розподілу тиску на фрюзеляжі, ГО, ВО, обтічнику. Книга 2.2.а (фюзеляж - частина 2.a).

- Експрес-звіт. Визначення розподілу тиску на фрюзеляжі, ГО, ВО, обтічнику. Книга 2.2.а (фюзеляж - частина 2.б).

- Звіт про науково-дослідну роботу. Розрахункові дослідження кінцевих аеродинамічних поверхонь літака Ан-148.

- Звіт. Експериментальні дослідження аеродинамічної моделі 002ИМС148.106 літака Ан-148 в аеродинамічній трубі Т-106М 3 варіантами зализів і мотогондолою МГ-10.

- Звіт. Експериментальні дослідження аеродинамічних моделей 
002ИМС148.106, 002КМС148.106, 002ЛМС148.106 літака Ан-148 в аеродинамічній трубі Т-106М.

- Звіт про науково-дослідну роботу. Експериментальні дослідження аеродинамічної моделі 002МС148.106 варіанта розвитку аеродинамічного компонування літака Ан-148 в аеродинамічній трубі Т-106М. Вагові випробування.

- Звіт про науково-дослідну роботу. Експериментальні дослідження аеродинамічної моделі 002МС148.106 варіанта розвитку аеродинамічного компонування літака Ан-148 в аеродинамічній трубі Т-106М. Фізичні випробування.

- Звіт. Аналіз результатів випробувань та оцінювання розвитку аеродинамічного компонування літака Ан-148.

- Експрес-звіт. Визначення розподілу тиску на фрюзеляжі, ГО, ВО, обтічнику.

- Експрес-звіт. Визначення розподілу тиску на фюзеляжі, ГО, ВО, обтічнику. Книга 2.1.б (фюзеляж - частина 1.б).

Перелік звітів за результатами дослідження аеродинамічних характеристик літака Ан-158 на моделях в аеродинамічній трубі АТ-1 ДП «АНТОНОВ»:

- Результати досліджень в аеродинамічній трубі АТ-1 виконавчої механізованої моделі літака Ан-148-200 (003КМС148.001). Науковотехнічний звіт.

- Результати випробувань в аеродинамічній трубі АТ-1 виконавчої моделі літака Ан-148-200 (03КМС 148.001) щодо визначення ефективності горизонтального оперення, руля висоти і руля напрямку. Звіт.

- Результати випробувань в аеродинамічній трубі АТ-1 виконавчої моделі літака Ан-148-200 (003КМС 148.001) щодо визначення ефективності елеронів та інтерцепторів. Звіт.

- Результати випробувань в аеродинамічній трубі АТ-1 моделі літака Ан-158 (003КМС148.001) щодо визначення місцевих кутів атаки та статичного тиску в області розміщення приймачів бортових засобів вимірювання. Технічна довідка.

- Результати досліджень в аеродинамічній трубі АТ-1 моделі літака Ан-158 (003КМС 148.001) щодо визначення впливу досліджених варіантів кінцевих аеродинамічних поверхонь. Науково-технічний звіт.

- Результати випробувань в аеродинамічній трубі АТ-1 моделі літака Ан-158 (003КМС 148.001) щодо визначення основних аеродинамічних характеристик при круговій продувці. Технічна довідка.

- Результати випробувань в аеродинамічній трубі АТ-1 щодо оцінювання двох варіантів обтічників шасі літака Ан-178 на моделі літака Ан-158 (003КМС148.001). Технічна довідка.

- Результати випробувань в аеродинамічній трубі АТ-1 моделі літака Ан-158 (003КМС 148.001) щодо визначення аеродинамічних характеристик і ефективності руля висоти на великих кутах атаки. Звіт.

- Результати випробувань в аеродинамічній трубі АТ-1 моделі консольної частини крила літака Ан-158 (008ПМК148.001) щодо визначення впливу зменшення підрізки профрілю 68а в області елерона на аеродинамічні характеристики моделі та шарнірні моменти елерона. Технічна довідка. 
ЦАГІ:

Перелік звітів за результатами випробувань моделей літака Ан-158 в

- Науково-технічний звіт. Дослідження посадки на воду моделі літака Aн-148-200.

- Звіт про науково-технічну роботу. Експериментальні дослідження аеродинамічної моделі 002МС 148.106 літака Ан-148-200 з КАП12АЗ у аеродинамічній трубі Т-106М.

- Звіт про науково-технічну роботу. Дослідження характеристик штопора моделі літака Ан-158 у вертикальній аеродинамічній трубі Т-105.

Матеріали випробувань виконавчих моделей літаків сімейства Ан-148/Ан-158 лягли в основу розроблення вихідних аеродинамічних характеристик літака для подальшого розрахунку його злітно-посадкових і льотно-технічних характеристик, а також характеристик стійкості, керованості і динаміки польоту.

\section{Основні висновки щодо аеродинаміки літаків}

1. Досягнутий рівень аеродинамічної досконалості літаків забезпечив виконання заданих вимог до їх льотно-технічних характеристик - максимальної швидкості, висоти крейсерського польоту та дальності польоту 3 різним комерційним навантаженням.

2. Розроблено аеродинамічне компонування, яке дозволило створити сімейство регіональних пасажирських літаків-високопланів зі швидкістю польоту до 870 км/год ІШ (M = 0,8), яке не має аналогів у світовій практиці авіабудування.

3. Основу аеродинамічного компонування швидкісного крила з помірною стрілоподібністю сімейства літаків Ан-148-100/Ан-158 склали розроблені для нього надкритичні профрілі нового покоління з великою максимальною відносною товщиною (більшою, наприклад, ніж у літаків Airbus A320 та Ан-124). Значення аеродинамічної якості літака на крейсерському режимі польоту становить $K_{\text {крейс }}=15,8$, що відповідає світовому рівню.

4. Розроблено аеродинамічне компонування механізації крила, яке забезпечило високі несучі властивості крила на етапах зльоту та посадки, що дозволило повністю виконати вимоги до необхідних довжин злітно-посадкових смуг аеродромів базування $L_{3 \Pi C}=1485 \ldots 1950$ м.

5. Необхідні за нормами характеристики стійкості, керованості та динаміки польоту в основному режимі керування забезпечуються розробленими алгоритмами, які реалізуються в електродистанційній системі керування. Вибрані запаси власної статичної стійкості літака, ефективність його органів керування забезпечують безпечне завершення польоту в резервному режимі керування.

6. Сертифрікаційні льотні випробування літаків Ан-148-100/Ан-158 підтвердили повну відповідність їх злітно-посадкових та льотно-технічних характеристик, а також характеристик стійкості, керованості та динаміки польоту вимогам Сертифікаційного базису як в штатних, так і у відмовних ситуаціях, що виносилися на льотні випробування.

7. Літаки як об'єкти керування в штатних і відмовних ситуаціях отримали високу оцінку пілотів, що є важливим чинником при формуванні замовлень на дані літаки потенційними експлуатантами. 


\section{Основні висновки}

\section{за експериментальними аеродинамічними дослідженнями}

1. Були проведені в необхідному і достатньому обсязі експериментальні роботи у низькошвидкісних і високошвидкісних аеродинамічних трубах ДП «АНТОНОВ» і ЦАГІ щодо дослідження аеродинамічних і штопорних характеристик моделей літаків Ан-148-100/Ан-158.

2. За результатами аеродинамічних експериментальних досліджень було покращено аеродинамічне компонування літаків у цілому та окремих їх агрегатів, розроблені вихідні аеродинамічні характеристики для визначення льотно-технічних і злітно-посадкових характеристик, а також характеристик стійкості, керованості й динаміки польоту.

3. Експериментальні і розрахункові аеродинамічні характеристики були застосовані при розрахунку літаків на міцність, а також для проектування систем літаків.

\section{Список літератури}

1. Нормы летной годности самолетов транспортной категории (АП-25). М.: МАК, 1994. - 322 с.

2. Кудрявцев, В. А. Некоторые особенности аэродинамического проектирования скоростного высокоплана [Текст]: доклад / В. А. Кудрявцев. - Москва: Международная конференция «НОВЫЕ РУБЕЖИ АВИАЦИОННОЙ НАУКИ», 2007. -268 c.

3. Кудрявцев, В.А. Основные результаты аэродинамического проектирования скоростного высокоплана [Текст]: доклад / В. А. Кудрявцев. - Киев: Нац. авиационный университет, Научно-практическая конференция «Аэродинамика и безопасность полетов», 2007.

4. Гребеников, А. Г. Методология интегрированного проектирования и моделирования сборных самолетных конструкций [Текст]: монографрия / А. Г. Гребеников. - Харьков: Нац. аэрокосм. ун-т «ХАИ», 2006. - 532 с.

\section{Reference}

1. Normy letnoj godnosti samoletov transportnoj kategorii (AP-25) [Part 25. Airworthiness Standards: Transport Category Airplanes]. - M.: MAK, 1994. - 322 p.

2. Kudrjavcev, V. A. Nekotorye osobennosti ajerodinamicheskogo proektirovanija skorostnogo vysokoplana [Some features of the aerodynamic design of high-speed high-wing airplane]: report / V. A. Kudrjavcev. - Moscow: International Conference "NEW FRONTIER OF AVIATION SCIENCE", 2007. - 268 p.

3. Kudrjavcev, V. A. Osnovnye rezul'taty ajerodinamicheskogo proektirovanija skorostnogo vysokoplana [The main results of the aerodynamic design of high-speed high-wing airplane]: report / V. A. Kudrjavcev. - Kiev: National Aviation University, Scientific-practical conference "Aerodynamics and flight safety", 2007.

4. Grebenikov, A. G. Metodologija integrirovannogo proektirovanija i modelirovanija sbornyh samoletnyh konstrukcij [Methodology of integrated design and simulation of prefabricated aircraft structures]: monograph / A. G. Grebenikov. Kharkov: National Aerospace University «KhAl», 2006. - 532 p.

Надійшла до редакції 25.02.2019, розглянута на редколегії 28.02.2019 


\section{Specifics of Providing the Regional Passenger Aircraft Aerodynamic Characteristics}

Principal results of the computational and research work performed during development of a regional passenger aircraft to ensure its aerodynamic characteristics are given. When creating the An-148-100/An-158 family of aircraft, such level of the aircraft aerodynamic perfection was achieved, which ensured fulfillment of the specified requirements for their flight performance - maximum speed, cruising flight altitude and flight range with different payloads. The developed aerodynamic configuration made it possible to create a family of regional passenger high-wing planes with a flight speed of up to $870 \mathrm{~km} / \mathrm{h}$ (true speed) $(\mathrm{M}=0.8)$, which have no analogues in the world aviation industry. Developed for the An-148-100 / An158 aircraft, supercritical profiles of the new generation with a large maximum relative thickness formed the basis of the aerodynamic configuration of a high-speed wing with moderate sweep. The aircraft lift-to-drag ratio in cruise flight is $K_{\text {cruise }}=15.8$, which corresponds to the worldwide values. Developed aerodynamic configuration of the wing high-lift devices provides high bearing properties of the wing during take-off and landing stages, which allows to fully meet the requirements for the runway required length of the base airfields $L_{r u n}=1485 \ldots 1950 \mathrm{~m}$. Developed algorithms are implemented in the electric remote control system and provide necessary standard characteristics of stability, controllability and flight dynamics in the main control mode. Selected margins of the aircraft's own static stability and effectiveness of its controls ensure safe completion of the flight in standby control mode.

The certification flight tests of the An-148-100/An-158 airplanes confirmed full compliance of their take-off and landing performance, as well as the stability, controllability and flight dynamics characteristics with the requirements of the Certification basis in both standard and in failure situations tested in flight tests. Necessary and sufficient amount of experimental work was conducted in the lowspeed and high-speed wind tunnels of the ANTONOV SC and TsAGI to verify the aerodynamic and spin characteristics of the An-148-100/An-158 airplane models, which improved the aerodynamic configuration of the aircraft and its individual units and allowed to apply the work results in calculation of aircraft strength, as well as for development of their systems.

Keywords: regional passenger aircraft, aerodynamic characteristics, aerodynamic configuration, flight performance, supercritical profile, flight dynamics, experimental aerodynamic studies.

\section{Відомості про авторів:}

Донець Олександр Дмитрович - Президент ДП «АНТОНОВ», м. Київ.

Кудрявцев Володимир Олександрович - заступник Генерального конструктора, начальник відділення аеродинаміки ДП «АНТОНОВ». 